\title{
Measuring the Activity of European and African Countries Using Social Accounting Matrices
}

43 Pages - Posted: 28 Oct 2011 - Last revised: 14 Nov 2011

Susana Santos

ISEG (School of Economics and Management) of the University of Lisboa; UECE (Research Unit on Complexity and Economics) and DE (Department of Economics)

Date Written: October 16, 2011

\section{Suggested Citation:}

Santos, Susana, Measuring the Activity of European and African Countries Using Social Accounting Matrices (October 16, 2011). Available at SSRN: https://ssrn.com/abstract=1944735 or http://dx.doi.org/10.2139/ssrn.1944735 


\section{Measuring the activity of European and African Countries using Social Accounting Matrices.}

Susana Santos

ISEG (School of Economics and Management)/UTL (Technical University of Lisbon); DE Department of Economics and UECE - Research Unit on Complexity and Economics ${ }^{(*)}$

Rua Miguel Lupi, 20, 1249-078 Lisboa, Portugal

Tel.: +3512139259 12; Fax: +351213971196

E-mail: ssantos@iseg.utl.pt

\section{Abstract:}

Economic models at the micro, meso and macro levels presuppose the existence of consistent databases that make it possible to quantify the activity of enterprises, sectors, regions, countries or continents. Such models can also be important aids in the policy decision process, since they permit the construction of scenarios resulting from the adoption of policy measures and the consequent changes that they introduce.

When consistent with the United Nations System of National Accounts (SNA), the Social Accounting Matrix (SAM) can include all the nominal flows of the measured part of the economy, at the level of both production and the institutions, and therefore satisfies these requirements. Thus, in its numerical version, a SAM constitutes a database and provides a snapshot of the measured reality at a certain moment, whereas its possible algebraic versions, i.e. models that are based upon it, permit the construction of the above-mentioned scenarios.

The possibility and usefulness of constructing SAMs for African countries consistent with the SNA will be examined and experimented. The SAM's basic structure and consistency within the whole system will be studied, as well as any possible disaggregations, extensions, aggregates, indicators and balances that can be calculated. Other aspects beyond that basic structure will also be examined in order to show to what extent the SAM is capable of covering parts of the economy that are not covered by the SNA.

Key words: Social Accounting Matrix; National Accounts; European Countries; African Countries JEL classification: C82; E01; E61.

(November 2011)

\footnotetext{
${ }^{(*)}$ UECE (Research Unit on Complexity and Economics) is financially supported by FCT (Fundação para a Ciência e a Tecnologia), Portugal. This paper is part of the Strategic Project 2011-12 (PEst-OE/EGE/UI0436/2011).
} 


\section{CONTENTS}

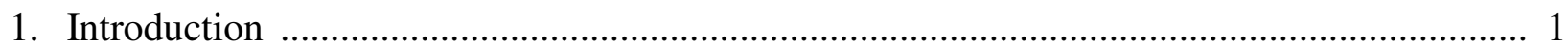

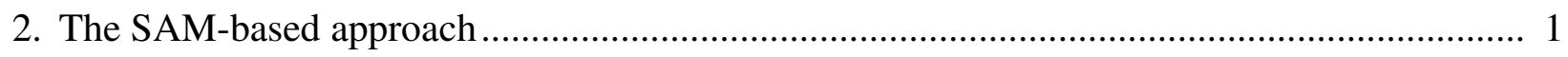

3. Constructing numerical versions of SAMs from the SNA. Applications to Portugal and

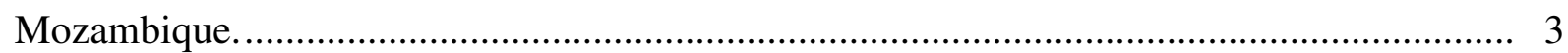

3.1. Basic structure and consistency with the whole system ............................................. 4

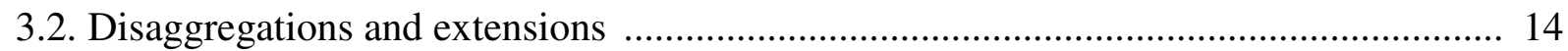

3.2.1. Production and trade accounts ....................................................................... 15

3.2.2. Institutions and Rest of the World accounts ................................................ 16

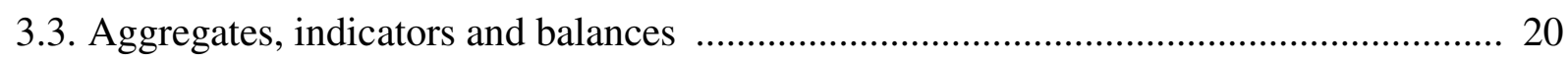

3.4. Examples of policy-type questions that can be addressed using SAMs ........................ 27

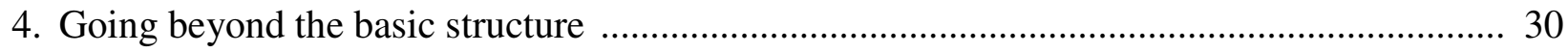

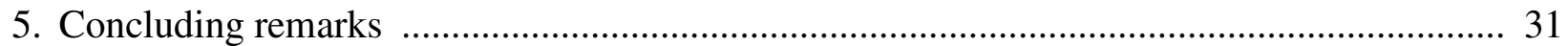

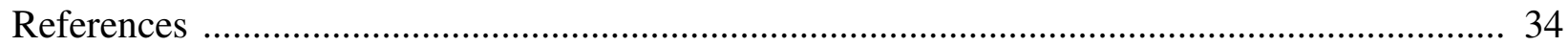

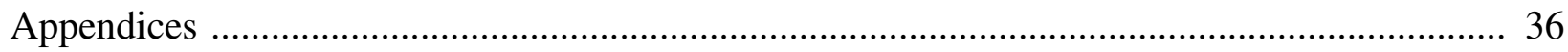




\section{Introduction}

In this paper ${ }^{1}$, the Social Accounting Matrix (SAM) will be presented as a tool for measuring the activity of countries, underlying which there are systems that can be worked upon in different ways. Thus, the SAM will be presented as an alternative support for studies being undertaken in several areas, as well as for those who intervene in the policy decision process, which can be directed towards different parts of those systems.

Adopting a conceptual framework based on the works of Graham Pyatt and his associates, Section 2 specifies the main features of the SAM-based approach, according to which the SAM can describe the activity of countries either empirically or theoretically, depending on whether it is presented in a numerical or an algebraic version, respectively.

Based upon the above-mentioned conceptual framework, Section 3 proposes some guidelines for the construction of numerical versions of SAMs, adopting the national accounts based on the United Nations System of National Accounts (SNA) as the base source of information. Different possibilities of analysis, provided by aggregates, indicators and balances that can be calculated from such versions, will precede two examples of policy-type questions that can be addressed using the same tool. In order to provide some empirical evidence as to how that proposal can be adopted worldwide, the exposition will be accompanied by the applications of a SAM to both a European country (Portugal) and an African country (Mozambique).

Section 4 examines certain aspects that lie outside the basic structure, which were presented in the previous section.

A SAM, will therefore be proposed that can include practically all the nominal flows measured using the SNA and which also has room for at least some of those flows that until now have not been measured. The concluding remarks, presented in Section 5, systematise the main ideas of the other sections in order to show to what extent countries can use SAMs to study (socio-)economic systems and support policy decision processes and other studies.

\section{The SAM-based approach}

Richard Stone and Graham Pyatt played a key role in the implementation of the SAM-based approach. Both worked on the conceptual details of that approach: the former worked more in numerical terms, within the framework of a system of national accounts, while the latter worked

\footnotetext{
${ }^{1}$ Based on the papers presented to the 19th International Input-Output Conference, held in Alexandria - Virginia, USA, on 13-17/6/2011, and to the Conference on Experiences and Challenges in Measuring National Income, Wealth, Poverty, and Inequality in African Countries - Cape Town, South Africa, on 28/9-1/10/2011.
} 
more in algebraic terms, mainly within the scope of input-output analysis. Their work has been decisive for understanding the importance of the SAM as a measurement tool.

In the foreword to the book that can now be regarded as a pioneering work in terms of the SAMbased approach, "Social Accounting for Development Planning with special reference to Sri Lanka", Richard Stone stated that the framework of the system of national accounts can be rearranged and "the entries in a set of accounts can be presented in a matrix in which, by convention (...), incomings are shown in the rows and outgoings are shown in the columns; and in which, reflecting the fact that accounts balance, each row sum is equal to the corresponding column sum." That matrix, with an equal number of rows and columns, is the SAM, in the construction of which "it may be possible to adopt a hierarchical approach, first adjusting the entries in a summary set of national accounts and then adjusting subsets of estimates to these controlling totals." (Pyatt and Roe, 1977: xix, xxiii).

In turn, in the abstract to his article, "A SAM approach to modeling”, Graham Pyatt says: "Given that there is an accounting system corresponding to every economic model, it is useful to make the accounts explicit in the form of a SAM. Such a matrix can be used as the framework for a consistent dataset and for the representation of theory in what is called its transaction form." In that transaction form (or TV (transaction value) form), the SAM can be seen ... "as a framework for theory" and its cells..."can be filled instead with algebraic expressions, which describe in conceptual terms how the corresponding transaction values might be determined". Thus, the SAM is used as "the basic framework for model presentation." (Pyatt, 1988: 327; 337).

Looking at the question from the perspectives outlined above, it can be said that a SAM can have two versions: a numerical version, which describes the activity of a society empirically; and an algebraic version, which describes that same activity theoretically. In the former version, each cell has a specific numerical value, with the sums of the rows being equal to the sums of the columns. In the latter version, each cell is filled with algebraic expressions that, together with those of all the other cells, form a SAM-based model, the calibration of which involves a replication of the numerical version.

In the words of Graham Pyatt, "the essence of (...) the SAM approach to modelling is to use the same SAM framework for both the empirical and the theoretical description of an economy." (Pyatt, 1988: 337).

In 1953, with the first and most fundamental contribution written by Richard Stone, the United Nations implemented the System of National Accounts (SNA), which continued to be published in successive versions until 2008 (ISWGA, 2008). This system establishes the rules for measuring the 
activity of countries or groups of countries, which, in turn, have been adopted and adapted to specific realities by the corresponding statistical offices.

The construction of algebraic versions can be seen, among others, in Pyatt (2001; 1988), Pyatt and Roe, (1977), Pyatt and Round (1985), Santos (2010; 2009).

Special attention has been paid by the author to the construction of numerical versions of SAMs from the SNA, a question which will be examined below.

\section{Constructing numerical versions of SAMs from the SNA. Applications to Portugal and Mozambique.}

The latest versions of the SNA have devoted a number of paragraphs to discussing the question of SAMs. The 2008 version mentions SAMs in Section D of Chapter 28, entitled "Input-output and other matrix-based analysis" (ISWGA, 2008: 519-522), in which a matrix representation is presented of the accounts identified and described in the whole SNA. This representation is not to be identified with the SAM presented in this paper, although they both cover practically all the transactions recorded by those accounts. The SAM that will be presented below results from the work that the author has undertaken within a conceptual framework based on the works of Graham Pyatt and his associates (Pyatt, 1988 and 1991; Pyatt and Roe, 1977; Pyatt and Round, 1985) and from the efforts made to reconcile that framework with what has been defined by (the successive versions of) the SNA (Pyatt, 1985 and 1991a; Round, 2003; Santos, 2009). Thus, the author will propose a version of the SAM that, as will be seen, is representative of practically all the nominal flows measured by the SNA.

Working within the framework of the European System of National and Regional Accounts in the European Community of 1995 (the adaptation for Europe of the 1993 version of the SNA), Santos (2007) makes an application to Portugal at an aggregate level, explaining the main differences between the two matrices mentioned above - the matrix representation of the SNA accounts and the author's own version of the SAM. Pyatt (1999) and Round (2003) also approach this same issue with their own versions.

Because the general differences between the accounts identified and described in the 1993 and 2008 versions of the SNA are not significant, this analysis still remains valid. It is also valid for the applications to Portugal and Mozambique in 2007, presented in the following subsections. In 2007, the Portuguese national accounts adopted the above-mentioned European System, based on the 1993 version of the SNA. In turn, as one of the 22 countries belonging to the project for Anglophone Africa of the General Data Dissemination System (GDDS), promoted by the International Monetary Fund (IMF), Mozambique produced its own national accounts following the 
recommendations of that same version of the $\mathrm{SNA}^{2}$. The sources of information and methodological details of the application to Mozambique are described in Appendix B.

Thus, following on from what was said above, a square matrix will be worked upon, in which the sum of the rows is equal to the corresponding sum of the columns. In keeping with what is conventionally accepted, resources, incomes, receipts or changes in liabilities and net worth will be represented in the entries made in the rows, while uses, outlays, expenditures or changes in assets will be represented in the entries made in the columns. Each transaction will therefore be recorded only once, in a cell of its own.

The starting point for the construction of a numerical SAM should be its design, i.e. the classification of its accounts, which will depend on the purposes for which it is to be used. By adopting the SNA as the underlying base source of information, a basic structure is proposed and the consistency of the whole system is highlighted. The flexibility of that basic structure will be shown, together with the possibilities that it presents for characterising any problem and for achieving the purposes of any study.

\subsection{The SAM's basic structure and its consistency with the whole system}

Adopting the working method recommended by Richard Stone in the second paragraph of Section 2 of this paper, the basic structure for the SAM presented here will be a summary set of the national accounts and the controlling totals for the other levels of disaggregation. Thus, in keeping with the conventions and nomenclature defined by the SNA, besides a rest of the world account, the proposed SAM will also include both production and trade accounts and institutional accounts.

Table 1 shows the above-mentioned basic structure, representing nominal transactions (" $\mathrm{t}$ ") with which two indexes are associated. The location of these transactions in the matrix framework is described by those indexes, the first of which represents the row account and the second the column account. Each cell of this matrix will be converted into a submatrix, with the number of rows and columns corresponding to the level of disaggregation of the row and column accounts.

\footnotetext{
${ }^{2}$ More details of Mozambique's participation in this data system can be found on the website of the GDDS Metadata by Country - Mozambique (http://dsbb.imf.org/Pages/GDDS/CtyCtgList.aspx?ctycode=MOZ)
} 
Measuring the activity of European and African Countries using Social Accounting Matrices. S.Santos

Table 1. The basic SAM

\begin{tabular}{|c|c|c|c|c|c|c|c|c|}
\hline & $\mathrm{p}$ & $a$ & $\mathrm{f}$ & dic & dik & dif & rw & total \\
\hline $\mathrm{p}$ - products & $t_{p, p}$ & $\mathrm{t}_{\mathrm{p}, a}$ & 0 & $t_{p, \text { dic }}$ & $t_{\mathrm{p}, \text { dik }}$ & 0 & $t_{\mathrm{p}, \mathrm{rw}}$ & $t_{\mathrm{p}}$. \\
\hline$a-$ activities & $\mathrm{t}_{a, \mathrm{p}}$ & 0 & 0 & 0 & 0 & 0 & 0 & $\mathrm{t}_{a}$ \\
\hline$f$ - factors & 0 & $\mathrm{t}_{\mathrm{f}, a}$ & 0 & 0 & 0 & 0 & $\mathrm{t}_{\mathrm{f}, \mathrm{rw}}$ & $t_{\mathrm{f}}$. \\
\hline dic - (domestic) institutions' current account & $t_{\text {dic,p }}$ & $\mathrm{t}_{\mathrm{dic}, a}$ & $t_{\text {dic,f }}$ & $\mathrm{t}_{\mathrm{dic}, \mathrm{dic}}$ & 0 & 0 & $t_{\text {dic,rw }}$ & $t_{\text {dic. }}$ \\
\hline dik - (domestic) institutions' capital account & 0 & 0 & 0 & $\mathrm{t}_{\text {dikdic }}$ & $\mathrm{t}_{\text {dik,dik }}$ & $t_{\text {dik,dif }}$ & $t_{\text {dik,rw }}$ & $\mathrm{t}_{\text {dik. }}$ \\
\hline dif - (domestic) institutions' financial account & 0 & 0 & 0 & 0 & 0 & $t_{\text {dif,dif }}$ & $t_{\text {dif,rw }}$ & $t_{\text {dif. }}$ \\
\hline rw - rest of the world & $t_{\text {rw,p }}$ & $\mathrm{t}_{\mathrm{rw}, a}$ & $\mathrm{t}_{\mathrm{rw}, \mathrm{f}}$ & $\mathrm{t}_{\mathrm{rw} \text {,dic }}$ & $\mathrm{t}_{\mathrm{rw}, \mathrm{dik}}$ & $\mathrm{t}_{\mathrm{rw} \text {,dif }}$ & & $\mathrm{t}_{\mathrm{rw}}$ \\
\hline Total & t.p & t. $a$ & $t_{\text {.f }}$ & t.dic & t.dik & t.dif & t. $\mathrm{sw}$ & \\
\hline
\end{tabular}

Sources: Santos (2010).

Note: The first three accounts ( $\mathrm{p}=$ products, $a=$ activities and $\mathrm{f}=$ factors (of production)) are the production and trade accounts of the economy and the next three accounts (dic = current; dik $=$ capital; dif $=$ financial $)$ are the accounts of the (domestic) institutions. The last account $(\mathrm{rw}=$ rest of the world) represents the "outside" part of the (domestic) economy.

Table 2 shows the transactions of the National Accounts recorded in the cells of the basic SAM, which will continue to be the same if some disaggregation, or even extension, is performed thereby preserving the consistency of the whole system.

Table 2. The National Accounts transactions in the cells of the basic SAM

\begin{tabular}{|l|l|l|c|c|}
\hline \multicolumn{2}{|c|}{ SAM } & \multicolumn{2}{c|}{ National Accounts transactions } \\
\hline row & column & \multicolumn{1}{|c|}{ Description (valuation $\left.{ }^{3}\right)$} & $\begin{array}{c}\text { (SNA) } \\
\text { code }\end{array}$ & \multicolumn{1}{|c|}{ Description $\left(\right.$ valuation $\left.^{3}\right)$} \\
\hline $\mathrm{p}$ & $\mathrm{p}$ & trade and transport margins & --- & trade and transport margins \\
\hline$a$ & $\mathrm{p}$ & production (basic prices) & P1 & output (basic prices) \\
\hline
\end{tabular}

\footnotetext{
${ }^{3}$ In the transactions represented by the cells whose rows and/or columns represent production accounts, as well as in the aggregates and balances that can be calculated from these, as will be seen in Section 3.3, the following types of valuation are identified (regardless of whether one is working with current or constant (price) values): factor cost; basic, cif (cost-insurance-freight included) and fob (free on board) prices; purchasers' or market prices.

Factor cost represents the compensation of the factors (or the primary incomes due to labour and capital) used in the production process of the domestic economy, excluding taxes on production and imports (taxes on products and other taxes on production) and subsidies (subsidies on products and other subsidies on production). This type of valuation is considered in the SNA (Paragraph 265) to be complementary (ISWGNA, 2008: 22).

When other taxes on production, net of other subsidies on production, are added to the production value of the domestic economy at factor cost, we obtain the basic prices for the production that will be transacted in the domestic market and the fob price level of the part that will be exported. Imports, valued at cif prices, will be added at this level to the unexported part of domestic production to be transacted in the domestic market.

Purchasers' or market prices relate to those products, either domestically produced or imported, that are transacted in the domestic market. Here, the basic/cif prices will be increased by adding to them the trade and transport margins and the taxes net of subsidies on products.
} 
Measuring the activity of European and African Countries using Social Accounting Matrices. S.Santos

\begin{tabular}{|c|c|c|c|c|}
\hline \multicolumn{3}{|r|}{ SAM } & \multicolumn{2}{|r|}{ National Accounts transactions } \\
\hline row & column & Description (valuation ${ }^{3}$ ) & $\begin{array}{l}\text { (SNA) } \\
\text { code }\end{array}$ & Description (valuation ${ }^{3}$ ) \\
\hline dic & $\mathrm{p}$ & $\begin{array}{l}\text { net taxes on products (paid to domestic } \\
\text { institutions - general government) }\end{array}$ & \multirow{2}{*}{$\begin{array}{l}\text { D21- } \\
-D 31\end{array}$} & $\begin{array}{l}\text { taxes on products } \\
\text { minus }\end{array}$ \\
\hline \multirow[t]{2}{*}{ rw } & \multirow[t]{2}{*}{$\mathrm{p}$} & $\begin{array}{l}\text { net taxes on products (paid to the RW), } \\
\text { when these exist }\end{array}$ & & subsidies on products \\
\hline & & imports (cif prices) & P7 & imports of goods and services (cif prices) \\
\hline $\mathrm{p}$ & rw & exports (fob prices) & P6 & exports of goods and services (fob prices) \\
\hline $\mathrm{p}$ & $a$ & $\begin{array}{l}\text { intermediate consumption (purchasers' } \\
\text { prices) }\end{array}$ & $\mathrm{P} 2$ & $\begin{array}{l}\text { intermediate consumption (purchasers' } \\
\text { prices) }\end{array}$ \\
\hline $\mathrm{p}$ & dic & final consumption (purchasers' prices) & P3 & $\begin{array}{l}\text { final consumption expenditure (purchasers' } \\
\text { prices) }\end{array}$ \\
\hline $\mathrm{p}$ & dik & $\begin{array}{l}\text { gross capital formation (purchasers' } \\
\text { prices) }\end{array}$ & P5 & gross capital formation (purchasers' prices) \\
\hline $\mathrm{f}$ & $a$ & gross added value (factor cost) & $\begin{array}{l}\text { D1 } \\
\text { D4 } \\
\text { B2g } \\
\text { B3g }\end{array}$ & $\begin{array}{l}\text { compensation of employees } \\
\text { net property income } \\
\text { gross operating surplus } \\
\text { gross mixed income }\end{array}$ \\
\hline dic & $a$ & $\begin{array}{l}\text { net taxes on production (paid to } \\
\text { domestic institutions - general } \\
\text { government) }\end{array}$ & \multirow{2}{*}{$\begin{array}{l}\text { D29- } \\
-D 39\end{array}$} & \multirow{2}{*}{$\begin{array}{l}\text { other taxes on production } \\
\text { minus } \\
\text { other subsidies on production }\end{array}$} \\
\hline rw & $a$ & $\begin{array}{l}\text { net taxes on production (paid to the } \\
\text { RW), when these exist }\end{array}$ & & \\
\hline dic & $\mathrm{f}$ & gross national income & $\mathrm{B} 5 \mathrm{~g}$ & gross national income \\
\hline rw & $\mathrm{f}$ & compensation of factors to the RW & \multirow{2}{*}{$\begin{array}{l}\text { D1 } \\
\text { D4 }\end{array}$} & \multirow{2}{*}{$\begin{array}{l}\text { primary income paid to/received from the } \\
\text { rest of the world } \\
\text { compensation of employees } \\
\text { net property income }\end{array}$} \\
\hline $\mathrm{f}$ & rw & compensation of factors from the RW & & \\
\hline dic & dic & $\begin{array}{l}\text { current transfers within domestic } \\
\text { institutions }\end{array}$ & \multirow{3}{*}{$\begin{array}{l}\text { D5 } \\
\text { D6 } \\
\text { D7 } \\
\text { D8 }\end{array}$} & \multirow{3}{*}{$\begin{array}{l}\text { current taxes on income, wealth, etc. } \\
\text { social contributions and benefits } \\
\text { other current transfers } \\
\text { adjustment for the change in the net equity of } \\
\text { households in pension fund reserves }\end{array}$} \\
\hline rw & dic & current transfers to the RW & & \\
\hline dic & rw & current transfers from the RW & & \\
\hline $\operatorname{dik}$ & dic & gross saving & $\mathrm{B} 8 \mathrm{~g}$ & gross saving \\
\hline dik & dik & $\begin{array}{l}\text { capital transfers within domestic } \\
\text { institutions }\end{array}$ & \multirow{3}{*}{ D9 } & \multirow{3}{*}{ capital transfers } \\
\hline $\operatorname{dik}$ & rw & capital transfers from the RW & & \\
\hline rw & dik & capital transfers to the RW & & \\
\hline
\end{tabular}


Measuring the activity of European and African Countries using Social Accounting Matrices. S.Santos

\begin{tabular}{|c|c|c|c|c|}
\hline \multicolumn{3}{|r|}{ SAM } & \multicolumn{2}{|r|}{ National Accounts transactions } \\
\hline row & column & Description (valuation ${ }^{3}$ ) & $\begin{array}{l}\text { (SNA) } \\
\text { code }\end{array}$ & Description (valuation ${ }^{3}$ ) \\
\hline $\operatorname{dik}$ & dif & $\begin{array}{l}\text { - net lending/borrowing (see } \mathrm{k} \text { ) in de } \\
\text { description of the SAM blocks) }\end{array}$ & B9 & net lending/borrowing \\
\hline dif & dif & $\begin{array}{l}\text { financial transactions within domestic } \\
\text { institutions }\end{array}$ & $\begin{array}{l}\mathrm{F} 1 \\
\mathrm{~F} 2\end{array}$ & $\begin{array}{l}\text { monetary gold and special drawing rights } \\
\text { (SDRs) }\end{array}$ \\
\hline rw & dif & financial transactions to the RW & $\begin{array}{l}\text { F3 } \\
\text { F4 }\end{array}$ & $\begin{array}{l}\text { currency and deposits } \\
\text { securities other than shares }\end{array}$ \\
\hline dif & rw & financial transactions from the RW & $\begin{array}{l}\text { F5 } \\
\text { F6 } \\
\text { F7 }\end{array}$ & $\begin{array}{l}\text { loans } \\
\text { shares and other equity } \\
\text { insurance technical reserves } \\
\text { other accounts receivable/payable }\end{array}$ \\
\hline $\mathrm{p}$ & total & aggregate demand & \multicolumn{2}{|c|}{ row sum of the $\mathrm{p}$ account's cells (see above) } \\
\hline total & $\mathrm{p}$ & aggregate supply & \multicolumn{2}{|c|}{ column sum of the p account's cells (see above) } \\
\hline$a$ & total & production value & P1 & output (basic prices) \\
\hline total & $a$ & total costs & \multicolumn{2}{|c|}{ column sum of the $a$ account's cells (see above) } \\
\hline$f$ & total & & \multirow{2}{*}{\multicolumn{2}{|c|}{\begin{tabular}{|l} 
row sum of the f account's cells (see above) \\
column sum of the f account's cells (see above)
\end{tabular}}} \\
\hline total & f & aggregate factors income & & \\
\hline dic & total & & \multicolumn{2}{|c|}{ row sum of the dic account's cells (see above) } \\
\hline total & dic & aggregate income & \multicolumn{2}{|c|}{ column sum of the dic account's cells (see above) } \\
\hline dik & total & investment funds & \multicolumn{2}{|c|}{ row sum of the dik account's cells (see above) } \\
\hline total & dik & aggregate investment & \multicolumn{2}{|c|}{ column sum of the dik account's cells (see above) } \\
\hline dif & total & & \multicolumn{2}{|c|}{ row sum of the dif account's cells (see above) } \\
\hline total & dif & total tinancial transactions & \multicolumn{2}{|c|}{ column sum of the dif account's cells (see above) } \\
\hline rw & total & $\begin{array}{l}\text { value of transactions to the rest of the } \\
\text { world }\end{array}$ & \multicolumn{2}{|c|}{ row sum of the rw account's cells (see above) } \\
\hline total & rw & $\begin{array}{l}\text { value of transactions from the rest of } \\
\text { the world }\end{array}$ & \multicolumn{2}{|c|}{ column sum of the rw account's cells (see above) } \\
\hline
\end{tabular}

Source: Santos (2010). 
Schematically, the flows between the described accounts represent the circular flows in the economy, which, using the SAM description, can be seen in Outline 1.

Outline 1: The nominal flows between the accounts of the basic SAM

DOMESTIC ECONOMY

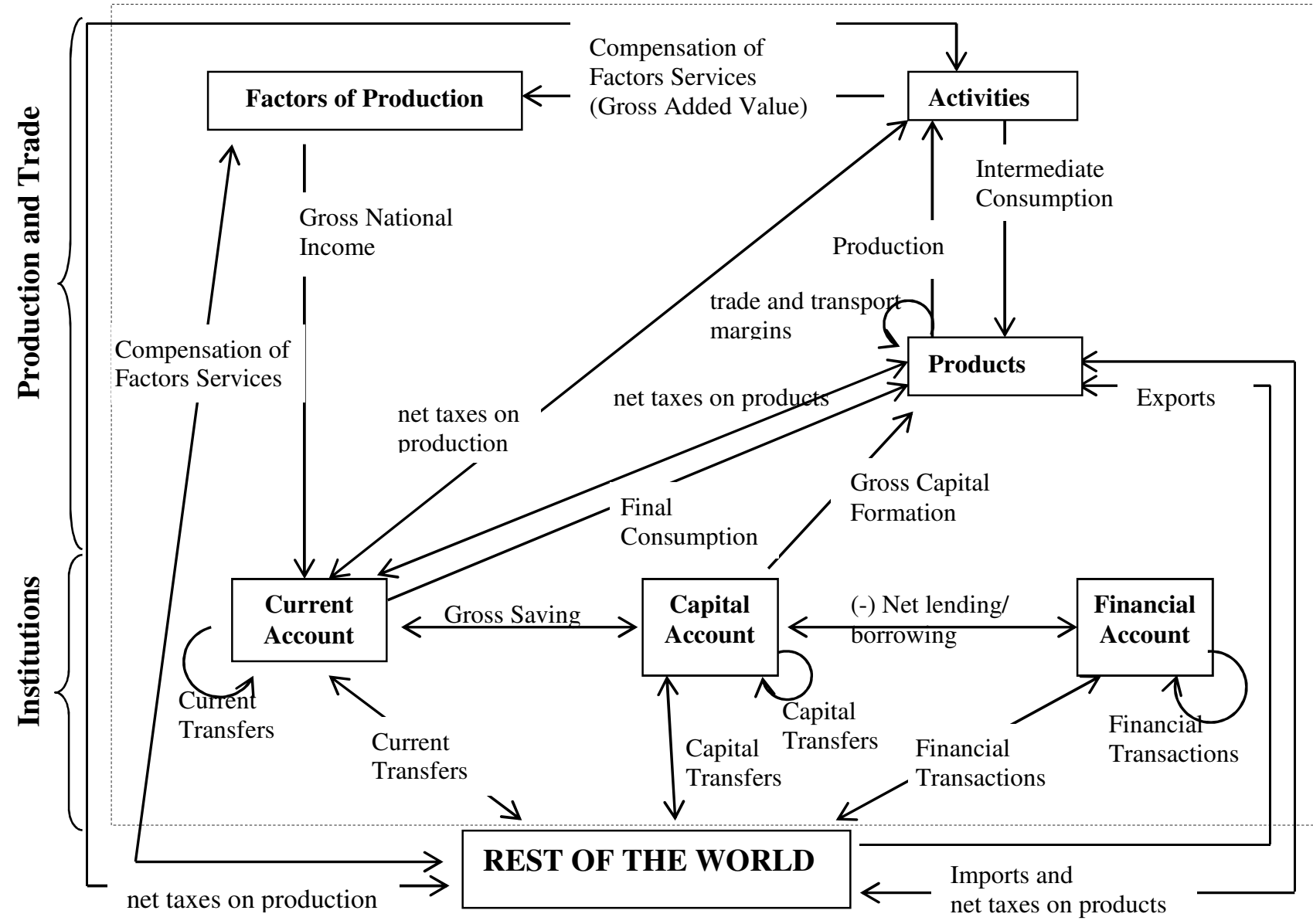

Source: Santos (2009: 6)

The SAM blocks, identified in Table 3, are submatrices or sets of submatrices with common characteristics. The specification of these blocks will be made below and involves an identification of the transactions of the National Accounts. 
Table 3. The basic SAM by blocks

\begin{tabular}{|c|c|c|c|c|c|c|c|}
\hline & $\mathrm{p}$ & $a$ & $\mathrm{f}$ & dic & dik & dif & rw \\
\hline $\mathrm{p}$ - products & $\begin{array}{l}\text { TTM } \\
\left(t_{p, p}\right)\end{array}$ & $\begin{array}{c}\mathrm{IC} \\
\left(\mathrm{t}_{\mathrm{p}, a}\right)\end{array}$ & 0 & $\begin{array}{c}\mathrm{FC} \\
\left(\mathrm{t}_{\mathrm{p}, \mathrm{dic}}\right)\end{array}$ & $\begin{array}{c}\mathrm{GCF} \\
\left(\mathrm{t}_{\mathrm{p}, \mathrm{dik}}\right)\end{array}$ & 0 & $\begin{array}{c}\mathrm{EX} \\
\left(\mathrm{t}_{\mathrm{p}, \mathrm{rw}}\right)\end{array}$ \\
\hline$a-$ activities & $\begin{array}{c}\mathrm{P} \\
\left(\mathrm{t}_{a, \mathrm{p}}\right)\end{array}$ & 0 & 0 & 0 & 0 & 0 & 0 \\
\hline $\mathrm{f}$ - factors & 0 & $\begin{array}{c}\text { CFP_GAV } \\
\left(\mathrm{t}_{\mathrm{f}, a}\right)\end{array}$ & 0 & 0 & 0 & 0 & $\begin{array}{l}\mathrm{CFP} \\
\left(\mathrm{t}_{\mathrm{f}, \mathrm{rw}}\right)\end{array}$ \\
\hline dic - (domestic) institutions' current account & $\begin{array}{c}\text { NTP } \\
\left(t_{d i c, p}\right) \\
\end{array}$ & $\begin{array}{c}\text { NTA } \\
\left(\mathrm{t}_{\mathrm{dic}, a}\right) \\
\end{array}$ & $\begin{array}{c}\text { CFP_GNI } \\
\left(\mathrm{t}_{\mathrm{dic}, \mathrm{f}}\right)\end{array}$ & $\begin{array}{c}\mathrm{CT} \\
\left(\mathrm{t}_{\mathrm{dic}, \mathrm{dic}}\right)\end{array}$ & 0 & 0 & $\begin{array}{c}\mathrm{CT} \\
\left(\mathrm{t}_{\mathrm{dic}, \mathrm{rw}}\right)\end{array}$ \\
\hline dik - (domestic) institutions' capital account & 0 & 0 & 0 & $\begin{array}{c}\mathrm{S} \\
\left(\mathrm{t}_{\mathrm{dik}, \mathrm{dic})}\right) \\
\end{array}$ & $\begin{array}{c}\mathrm{KT} \\
\left(\mathrm{t}_{\mathrm{dik}, \mathrm{dik}}\right)\end{array}$ & $\begin{array}{c}\text { NLB } \\
\left(t_{\text {dik,dif }}\right) \\
\end{array}$ & $\begin{array}{c}\mathrm{KT} \\
\left(\mathrm{t}_{\mathrm{dik}, \mathrm{rw}}\right)\end{array}$ \\
\hline $\begin{array}{l}\text { dif - (domestic) institutions' financial } \\
\text { account }\end{array}$ & 0 & 0 & 0 & 0 & 0 & $\begin{array}{c}\mathrm{FT} \\
\left(\mathrm{t}_{\mathrm{dif}, \mathrm{dif}}\right)\end{array}$ & $\begin{array}{c}\mathrm{FT} \\
\left(\mathrm{t}_{\mathrm{dif}, \mathrm{rw}}\right)\end{array}$ \\
\hline rw - rest of the world & $\begin{array}{c}\text { IM\&NTP } \\
\left(\mathrm{t}_{\mathrm{rw}, \mathrm{p}}\right)\end{array}$ & $\begin{array}{l}\mathrm{NTA} \\
\left(\mathrm{t}_{\mathrm{rw}, a}\right)\end{array}$ & $\begin{array}{l}\mathrm{CFP} \\
\left(\mathrm{t}_{\mathrm{rw}, \mathrm{f}}\right)\end{array}$ & $\begin{array}{c}\mathrm{CT} \\
\left(\mathrm{t}_{\mathrm{rw}, \mathrm{dic}}\right)\end{array}$ & $\begin{array}{c}\mathrm{KT} \\
\left(\mathrm{t}_{\mathrm{rw}, \mathrm{dik}}\right)\end{array}$ & $\begin{array}{c}\mathrm{FT} \\
\left(\mathrm{t}_{\mathrm{rw}, \mathrm{dif}}\right)\end{array}$ & 0 \\
\hline
\end{tabular}

Source: Santos $(2009 ; 2010)$

Description:

a) Production - P (cell: $\mathrm{t}_{a, \mathrm{p}}$ ) represents the output of goods and services (transaction P1 of the National Accounts).

b) Domestic Trade is represented by the value of domestically transacted products, which can be either domestically produced or imported.

b.1) Intermediate Consumption - IC (cell: $\mathrm{t}_{\mathrm{p}, a}$ ) consists of the value of the goods and services consumed as inputs through a process of production, excluding those fixed assets whose consumption is recorded as consumption of fixed capital (transaction P2 of the National Accounts).

b.2) Final Consumption - FC (cell: $t_{p, d i c}$ ) consists of the expenditure incurred by resident institutional units on those goods or services that are used for the direct satisfaction of individual needs or wants, or the collective needs of members of the community (transaction P3 of the National Accounts).

b.3) Gross Capital Formation - GCF (cell: $t_{p, d i k}$ ) includes: gross fixed capital formation (transaction P51 of the National Accounts), changes in inventories (transaction P52), and acquisitions minus disposals of valuables (transaction P53).

c) External Trade - includes the transactions in goods and services from non-residents to residents, also known as imports (transaction P7 of the National Accounts), or IM (cell: $\mathrm{t}_{\mathrm{rw}, \mathrm{p}}$ ), and the 
transactions in goods and services from residents to non-residents, also known as exports (transaction P6 of the National Accounts), or EX (cell: $\left.t_{p, r w}\right)$.

d) Trade and Transport Margins - TTM (cell: $t_{p, p}$ ) are realised on goods purchased for resale and are a part of the production of wholesale trade services, retail trade services and the repair services of motor vehicles, motorcycles and personal and household goods. They amount to zero, since they are negative in relation to the three above-mentioned activities (because the corresponding value has already been recorded in the production submatrix), but are positive and have the same amount in relation to all the other ones.

e) Net indirect taxes or net taxes on production and imports

e.1) Net Taxes on Production - NTA (cells: $\mathrm{t}_{\mathrm{dic}, a} ; \mathrm{t}_{\mathrm{rw}, a}$ ) represents the (other) taxes on production (transaction D29 of the National Accounts) minus the (other) subsidies to production (transaction D39 of the National Accounts).

e.2) Net Taxes on Products - NTP (cells: $t_{d i c, p} ; t_{r w, p}$ ) represents the taxes on products (transaction D21 of the National Accounts) minus the subsidies on products (transaction D31 of the National Accounts).

f) Compensation of factors of production - CFP (cells: $t_{\mathrm{f}, a} ; \mathrm{t}_{\mathrm{dic}, \mathrm{f}} ; \mathrm{t}_{\mathrm{f}, \mathrm{rw}} ; \mathrm{t}_{\mathrm{rw}, \mathrm{f}}$ ) consists of the income of the institutional sectors originating from the compensation of the services provided through their real and financial assets to the activities of production and to the rest of the world, namely the compensation of employees (transaction D1 of the National Accounts) and the compensation of own-account assets, including the compensation of employers and/or own-account workers, and of capital, namely property income (transaction D4, balances B2g and B3g of the National Accounts).

g) Current Transfers - CT (cells: $t_{\text {dic,dic }} ; t_{\text {dic,rw }} ; t_{\text {rw,dic }}$ ) includes: current taxes on income, wealth, etc. (transaction D5 of the National Accounts); social contributions (transaction D61); social benefits in cash (transaction D62); other current transfers (transaction D7); and the adjustment made for the change in the net equity of households in pension fund reserves (transaction D8).

h) Capital Transfers - KT (cells: $t_{\text {dik,dik }}$; $t_{\text {dik,rw; }} t_{\text {rw,dik }}$ ) includes: capital taxes (transaction D91 of the National Accounts), investment grants (transaction D92); other capital transfers (transaction D99); and acquisitions less disposals of non-financial non-produced assets (transaction K2)

i) Financial Transactions - FT (cells: $\left.t_{\text {dif,dif }} ; t_{d i f, r w} ; t_{r w, d i f}\right)$ represents the transactions in financial assets and liabilities between institutional units, and between these and the rest of the world. They are classified as monetary gold and special drawing rights; currency and deposits; 
securities other than shares; loans; shares and other equity; insurance technical reserves; and other accounts receivable/payable (F1-7 of the National Accounts).

j) Gross Saving - S (cell: $t_{\text {dik,dic }}$ ) measures the portion of aggregate income that is not used for final consumption expenditure and current transfers to domestic institutions or to the rest of the world.

k) Net borrowing/lending - NLB (cell: $\left.t_{\text {dik,dif }}\right)$.

The net lending (+) or borrowing (-) of the total economy is the sum of the net lending or borrowing of the institutional sectors. It represents the net resources that the total economy makes available to the rest of the world (if it is positive) or receives from the rest of the world (if it is negative). The net lending (+) or borrowing (-) of the total economy is equal (but with an opposite mathematical sign) to the net borrowing (-) or lending (+) of the rest of the world.

Here, those amounts that fall short of (+) or exceed (-) the investment funds used to cover aggregate investment are recorded in the capital and financial accounts, since they are financial transactions either from the rest of the world (in the case of net borrowing) or to the rest of the world (in the case of net lending). This is why the mathematical signs defined in the first paragraph of this item have been exchanged.

The construction of a SAM is easier when performed by blocks.

The integrated economic accounts table is equivalent to a summary of everything that is measured by the SNA. According to paragraph 2.75 of the 2008 SNA, "The integrated economic accounts use (...) three of the conceptual elements of the SNA (...) [institutional units and sectors, transactions and assets and liabilities] together with the concept of the rest of the world to form a wide range of accounts. These include the full sequence of accounts for institutional sectors, separately or collectively, the rest of the world and the total economy." (ISWGNA, 20008: 23). The table in Appendix A illustrates this situation for Portugal in 2007. Based on that table, and in view of the previous description, it can be said that (practically) all the transactions recorded by the national accounts are considered in the cells of the SAM. Table 4 illustrates its application to Portugal in 2007. No integrated economic accounts table was found for Mozambique and, from the information that was accessed, it was only possible to fill in the cells of the Basic SAM, as shown in Table 5. 
Measuring the activity of European and African Countries using Social Accounting Matrices.

S.Santos

Table 4. Basic SAM of Portugal in 2007 (unit: $10^{6}$ euros)

\begin{tabular}{|c|c|c|c|c|c|c|c|c|}
\hline & $\mathrm{p}$ & $a$ & $\mathrm{f}$ & dic & dik & dif & rw & total \\
\hline $\mathrm{p}$ - products & 0 & 171360 & & 141615 & 38634 & & 54514 & 406123 \\
\hline$a-$ activities & 317058 & & & & & & & 317058 \\
\hline $\mathrm{f}$ - factors & & 146564 & & & & & 13056 & 159620 \\
\hline dic - (domestic) institutions' current account & 22876 & 230 & 140287 & 80940 & & & 4841 & 249175 \\
\hline dik - (domestic) institutions' capital account & & & & 21473 & 1122 & 15061 & 2341 & 39997 \\
\hline dif - (domestic) institutions' financial account & & & & & & 48913 & 38471 & 87384 \\
\hline rw - rest of the world & $66188^{(a)}$ & -1096 & 19333 & 5147 & 241 & 23410 & & 113223 \\
\hline total & 406123 & 317058 & 159620 & 249175 & 39997 & 87384 & 113223 & \\
\hline
\end{tabular}

Source: Integrated Economic Accounts Table for Portugal in 2007 (Appendix A).

Note: Since direct purchases abroad by residents ( $2019 * 10^{6}$ euros) are not expenditures within the domestic economy, they were considered as a current transfer to the rest of the world and were therefore deducted from the final consumption of the households and from imports.

(a) $66188=66026$ (imports) +163 (net taxes on products sent to the rest of the world) 
Measuring the activity of European and African Countries using Social Accounting Matrices.

S.Santos

Table 5. Basic SAM of Mozambique in 2007 (unit: $10^{6}$ meticais)

\begin{tabular}{|c|c|c|c|c|c|c|c|c|}
\hline & $\mathrm{p}$ & $a$ & $\mathrm{f}$ & dic & dik & dif & rw & total \\
\hline $\mathrm{p}$ - products & 0 & 180731 & & 191137 & 31784 & & 64146 & 467798 \\
\hline$a$ - activities & 371384 & & & & & & & 371384 \\
\hline$f-$ factors & & 185920 & & & & & 4253 & 190173 \\
\hline dic - (domestic) institutions' current account & 16991 & 4732 & 172925 & & & & & \\
\hline dik - (domestic) institutions' capital account & & & & 19083 & & -1313 & & \\
\hline dif - (domestic) institutions' financial account & & & & & & & & \\
\hline rw - rest of the world & 79423 & & 17248 & & & & & \\
\hline Total & 467798 & 371384 & 190173 & & & & & \\
\hline
\end{tabular}

Sources: Instituto Nacional de Estatística de Moçambique; World Bank Databank by Country - Mozambique.

Notes: see the methodological details in Appendix B; the cells shaded in grey could not be filled in due to a lack of information. 
Therefore, as mentioned above and again using the words of Richard Stone, the basic SAM that has just been described is the most aggregate "summary set of national accounts" and can represent a first level of the intended hierarchical method (approach), with all the controlling totals for the next level of that hierarchy. However, it should be noted that, while this is almost completely true for countries such as Portugal, whose national accounts adopt and are completely adapted to the SNA, it is not true for countries such as Mozambique, whose adoption/adaptation is less complete, so that the national accounts provide much fewer possibilities for work, particularly in the case of institutional sectors. This means that we are still confronted with the problem already identified by Lury in 1964, in his article "National Accounts in Africa", when he emphasised the usefulness of having, in addition to the estimation of "the value of the stream of goods and services available to the community...”, “.. extra tables of government revenue and expenditure, and details of sources of savings from which investment is financed" (Lury, 1964: 99-100).

\subsection{Disaggregations and extensions}

Some other levels of the above-mentioned hierarchical method can be identified within the national accounts, providing other controlling totals for greater levels of disaggregation - with or without the use of national accounts. On the one hand, this will make it possible to maintain the consistency of the basic structure of the identified flows and the underlying network of linkages and interactions, and, on the other hand, it will allow us to analyse parts of that same structure in greater or lesser detail.

Thus, with the expected appearance of quarterly national accounts, although these will not be as complete as the annual ones, it will be possible to introduce some further disaggregation in terms of time.

Furthermore, disaggregations can be made in terms of space, since regional accounts are also considered. Here, with the same SNA, it is possible to work with regions and countries, either individually or as a group. Round $(1994 ; 1991)$, for example, experimented with the case of Europe. It would even be possible to think in world terms, if the SNA could be adopted worldwide.

Extensions are also possible, either from the national accounts or from other sources of information. The 2008 SNA dedicates its Chapter 28 to "Satellite accounts and other extensions" (ISWGNA, 2008: 523-544), where the main idea is to serve specific analytical purposes, in a way that is consistent with the central framework, although not fully integrated into it (ISWGNA, 2008: 37-38).

\footnotetext{
${ }^{4}$ Following on from a Conference held in January 1961, organised by the United Nations Economic Commission for Africa (UNECA) and the International Association for Research in Income and Wealth (IARIW), this article reviews the published papers and other relevant publications on "National Accounts in Africa".
} 
In this respect, the author would like to support Steven Keunning and Willem Ruijter's idea of a "complete data set" which "could be tentatively labelled: a System of Socio-economic Accounts" (Keunning and Ruijter, 1988: 73).

\subsubsection{Production and trade accounts}

In the basic structure described above, the production and trade accounts are the accounts of products, activities and factors of production. These accounts correspond respectively to the SNA accounts of goods and services, production and the primary distribution of income. Thus, within these accounts and depending on the available level of disaggregation, it can be seen how the available products are used, with some details being provided about the process of production and about how the incomes resulting from that process and the ownership of assets are distributed among institutions and activities (Santos, 2007).

The SNA uses the Central Product Classification (CPC) Version 2 (completed in December 2008) to classify products (ISWGNA, 2008: 19), which are organised into 10 sections, with it being possible to go to the 5 th level of disaggregation within each of these.

In turn, the International Standard Industrial Classification of All Economic Activities (ISIC) Revision 4 (officially released in August 2008) is used to classify the activities (ISWGNA, 2008: 20 ), organised into 23 sections, the disaggregation of which is perfectly consonant with that of the product classification. The Supply and Use Table provides this information, usually at an intermediate level of disaggregation.

As described above, in the characterisation of the block representing the compensation of factors of production, the possible disaggregation from the tables of the national accounts is between labour (or the compensation of employees) and what the author called the compensation of own assets, which includes the compensation of employers and/or own-account workers, and the compensation of capital, namely property income. Such information can only be derived from the Integrated Economic Accounts Table if the products and activities accounts are not disaggregated or from the Supply and Use Table if those accounts are disaggregated. Table 6, which contains the abovementioned application to Portugal, in which the products and activities accounts are not disaggregated, presents the possible disaggregation of the factors of production accounts based on the Integrated Economic Accounts Table (see Appendix A). In the case of Mozambique, where these accounts are not available, as explained above, everything that could be done is shown in Table 7. 
The extensions for tourism and health are presented by the SNA as examples of satellite accounts (ISWGNA, 2008: 531-534; 538-542).

\subsubsection{Institutions and Rest of the World accounts}

In the basic structure described above, the accounts of the domestic institutions are divided into current, capital and financial accounts. These accounts correspond respectively to the following SNA accounts: secondary distribution of income, redistribution of income in kind and use of income; capital; and financial accounts. Within these accounts, depending on the available level of disaggregation, the current accounts show how the national income is transformed into disposable income through the receipt and payment of current transfers, and how the latter is distributed between final consumption and saving. In turn, the capital account records the transactions linked to acquisitions of non-financial assets and capital transfers involving the redistribution of wealth, whereas the financial account records the transactions in financial assets and liabilities between institutional units, and between these and the rest of the world (Santos, 2007).

All the linkages between the domestic economy and the rest of the world, i.e. all the transactions between resident and non-resident units, are recorded both in the SAM and in the SNA through the rest of the world account (Santos, 2007).

Chapter 4 of the 2008 SNA specifies the institutional sectors, including the rest of the world, and their possible disaggregation, which in some cases can be taken as far as the third level (ISWGNA, 2008: 61-85), although normally it cannot be taken beyond the first level. In the case of the rest of the world, such disaggregation will certainly depend on the country, or group of countries, that adopt and adapt this system.

At the first level of disaggregation, the accounts of the institutions, as well as the rest of the world account, are part of the Integrated Economic Accounts Table. Higher levels of disaggregation, whenever these are possible, are usually published in the separate accounts of institutions.

Even at the first level of disaggregation, any work conducted with the institutional sectors requires, in addition to the Integrated Economic Accounts or the Accounts of the Institutions, the so-called "from whom to whom matrices", which are not normally published, but can be acquired from the national statistical offices. These matrices make it possible to fill in the cells of the submatrices of transactions taking place within domestic institutions, recorded in the above-described blocks of current and capital transfers and financial transactions.

The disaggregation of specific institutional sectors makes it possible to analyse the most diverse aspects of a country's activity: income distribution, with disaggregated households and factor of production accounts (Santos, 2009, is an example of this); the role of the government and its 
subsectors, with a disaggregated general government account (Santos, 2004 and 2007a, are other examples); the role of the non-profit institutions serving households, as well as of the non-financial and/or financial corporations, etc.

The detailed study of the specific accounts of domestic institutions and their corresponding transactions also makes it possible to analyse specific aspects of that same activity, namely: the distribution and redistribution of income, using the current account; redistribution of wealth, using the capital account; investment, its financing, and the implicit levels of the financing requirements and availability of the institutional sectors and the whole economy, using the capital and financial accounts. For more information on this last issue, see Roe (2003).

In turn, the rest of the world account can provide many possibilities for studying the international economic relations of the domestic economy.

Table 6 presents the possible disaggregation of the institutions' current and capital accounts, made from the Integrated Economic Accounts Table and the "from whom to whom matrices", for Portugal in 2007. Due to the unavailability of "from whom to whom matrices" for financial transactions, the financial account could not be disaggregated.

As can be seen in Table 7, it was almost completely impossible to make the same application for Mozambique, due to the already mentioned unavailability of integrated economic accounts tables, as well as the absence of "from whom to whom matrices". 
Measuring the activity of European and African Countries using Social Accounting Matrices.

S.Santos

Table 6. SAM of Portugal in 2007, with disaggregated factors of production and the (domestic) institutions' current and capital accounts (unit: $10^{6}$ euros)

\begin{tabular}{|c|c|c|c|c|c|c|c|c|c|c|c|c|c|c|c|c|c|c|c|c|c|c|c|}
\hline \multirow{3}{*}{\multicolumn{4}{|c|}{ Outlays (expenditures) }} & \multicolumn{5}{|c|}{ PRODUCTION } & \multicolumn{13}{|c|}{ NSTITUTIONS } & \multirow{3}{*}{$\begin{array}{l}\text { REST OF } \\
\text { THE } \\
\text { WORLD }\end{array}$} & \multirow{4}{*}{ TOTAL } \\
\hline & & & & \multirow[b]{2}{*}{ PRODUCTS } & \multirow[b]{2}{*}{ ACTIVITIES } & \multicolumn{3}{|c|}{ FACTORS } & \multicolumn{6}{|c|}{ CURRENT ACCOUNT } & \multicolumn{6}{|c|}{ CAPITAL ACCOUNT } & \multirow[b]{2}{*}{$\begin{array}{c}\text { FNANCLAL } \\
\text { ACCOUNT }\end{array}$} & & \\
\hline & & & & & & $\begin{array}{c}\text { Labour } \\
\text { (employees) }\end{array}$ & $\begin{array}{c}\text { Own } \\
\text { Assests }\end{array}$ & \multirow[t]{2}{*}{ Total } & Households & $\begin{array}{c}\text { Enterprises } \\
\text { (nonfinancial } \\
\text { corporations) }\end{array}$ & $\begin{array}{c}\text { Financial } \\
\text { corporations }\end{array}$ & Govemment & $\begin{array}{c}\text { NonProfitinsti- } \\
\text { tutionsServing } \\
\text { Households } \\
\text { (NPISH) } \\
\end{array}$ & \multirow[t]{2}{*}{ Total } & Households & $\begin{array}{c}\text { Enterprises } \\
\text { (nonfinancial } \\
\text { corporations) }\end{array}$ & \begin{tabular}{|c|} 
Financial \\
corporations
\end{tabular} & Govemment & \begin{tabular}{|c|} 
NonProfitinsti- \\
tutionsServing \\
Households \\
(NPISH) \\
\end{tabular} & \multirow[t]{2}{*}{ Total } & & & \\
\hline \multicolumn{4}{|c|}{ Incomes (receipts) } & 1 & 2 & 3 & 4 & & 5 & 6 & 7 & 8 & 9 & & 10 & 11 & 12 & 13 & 14 & & 15 & 16 & \\
\hline \multirow{5}{*}{$\begin{array}{l}z \\
\varrho \\
0 \\
0 \\
\frac{0}{2} \\
0 \\
0\end{array}$} & \multicolumn{2}{|c|}{ PRODUCTS } & 1 & 0 & 171360 & 0 & 0 & & 105201 & 0 & 0 & 32999 & 3415 & 141615 & 9287 & 23003 & 1683 & 4113 & 547 & 38634 & & 54514 & 406123 \\
\hline & \multicolumn{2}{|c|}{ ACTIVITIES } & 2 & 317058 & 0 & 0 & 0 & 0 & 0 & 0 & 0 & 0 & 0 & 0 & 0 & 0 & 0 & 0 & 0 & 0 & 0 & 0 & 317058 \\
\hline & \multirow{3}{*}{ 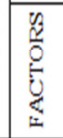 } & Labour (employees) & 3 & 0 & 82876 & 0 & 0 & 0 & 0 & 0 & 0 & 0 & 0 & 0 & 0 & 0 & 0 & 0 & 0 & 0 & 0 & 247 & 83123 \\
\hline & & Own Assets & 4 & 0 & 63688 & 0 & 0 & & 0 & 0 & 0 & 0 & 0 & 0 & 0 & 0 & 0 & 0 & 0 & 0 & 0 & 12809 & 76498 \\
\hline & & Total & & 0 & 146564 & 0 & 0 & & 0 & 0 & 0 & 0 & 0 & 0 & 0 & 0 & 0 & 0 & 0 & 0 & 0 & 13056 & 159620 \\
\hline \multirow{13}{*}{\multicolumn{2}{|c|}{ 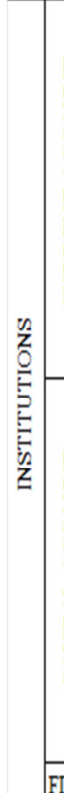 }} & Households & 5 & 0 & 0 & 82871 & 34809 & 117680 & 792 & 1715 & 5093 & 25060 & 64 & 32725 & 0 & 0 & 0 & 0 & 0 & 0 & 0 & 4162 & 154567 \\
\hline & & \begin{tabular}{|l|} 
Enterprises \\
(nonfinancial corporations)
\end{tabular} & 6 & 0 & 0 & 0 & 15972 & 15972 & 1711 & 0 & 705 & 141 & 0 & 2557 & 0 & 0 & 0 & 0 & 0 & 0 & & 88 & 18617 \\
\hline & & Financial corporations & 7 & 0 & 0 & 0 & 5918 & 5918 & 5143 & 627 & 133 & 24 & 29 & 5957 & 0 & 0 & 0 & 0 & 0 & 0 & & 73 & 11948 \\
\hline & & Govemment & 8 & 22876 & 230 & 0 & .230 & .230 & 29427 & 6423 & 1429 & 21 & 27 & 37328 & 0 & 0 & 0 & 0 & 0 & 0 & & 518 & 60723 \\
\hline & & \begin{tabular}{|l}
$\begin{array}{l}\text { NonProfititnstitutionsSer } \\
\text { vingHouseholds(NPISH) }\end{array}$ \\
\end{tabular} & 9 & 0 & 0 & 0 & 946 & 946 & 521 & 149 & 44 & 1660 & 0 & 2374 & 0 & 0 & 0 & 0 & 0 & 0 & & 0] & 3320 \\
\hline & & Total & & 22876 & 230 & 82871 & 57416 & 140287 & 37594 & 8914 & 7405 & 26905 & 121 & 80940 & 0 & 0 & 0 & 0 & 0 & 0 & & 4841 & 249175 \\
\hline & & Households & 10 & 0 & 0 & 0 & 0 & & 8551 & 0 & 0 & 0 & 0 & 8551 & 0 & 0 & 2 & 75 & 0 & 77 & -2265 & 3048 & 9411 \\
\hline & & \begin{tabular}{|l|} 
Enterprises \\
(nonfinancial corporations)
\end{tabular} & 11 & 0 & 0 & 0 & 0 & & 0 & 9473 & 0 & 0 & 0 & 9473 & 0 & 0 & 0 & 749 & 0 & 749 & 14762 & -1859 & 23125 \\
\hline & & Financial corporations & 12 & 0 & 0 & 0 & 0 & & 0 & 0 & 4432 & 0 & 0 & 4432 & 0 & 0 & 2 & 1 & 0 & 3 & -2692 & .55 & 1688 \\
\hline & & Govemment & 13 & 0 & 0 & 0 & 0 & & 0 & 0 & 0 & .767 & 0 & .767 & 11 & 22 & 0 & 0 & 1 & 34 & 4777 & 1181 & 5225 \\
\hline & & \begin{tabular}{|l}
$\begin{array}{l}\text { NonProfititnstitutionsSer } \\
\text { vingHouseholds(NPISH) }\end{array}$ \\
\end{tabular} & 14 & 0 & 0 & 0 & 0 & & 0 & 0 & 0 & 0 & -216 & -216 & 0 & 0 & 0 & 259 & 0 & 259 & 479 & 26 & 549 \\
\hline & & Total & & 0 & 0 & 0 & 0 & & 8551 & 9473 & 4432 & .767 & .216 & 21473 & 11 & 22 & 4 & 1084 & 1 & 1122 & 15061 & 2341 & 39997 \\
\hline & \multicolumn{2}{|c|}{ FNANCLAL ACCOUNT } & 15 & 0 & 0 & 0 & 0 & 0 & 0 & 0 & 0 & 0 & 0 & 0 & 0 & 0 & 0 & 0 & 0 & 0 & 48913 & 38471 & 87384 \\
\hline & STOF T & FE WORLD & 16 & 66188 & .1096 & 252 & 19081 & 19333 & 3221 & 230 & 111 & 1586 & 0 & 5147 & 113 & 100 & 0 & 28 & 0 & 241 & 23410 & & 113223 \\
\hline \multicolumn{3}{|c|}{ TOTAL } & & 406123 & 317058 & 83123 & 76498 & 159620 & 154567 & 18617 & 11948 & 60723 & 3320 & 249175 & 9411 & 23125 & 1688 & 5225 & 549 & \begin{tabular}{|l|l|}
39997 \\
\end{tabular} & 87384 & 113223 & \\
\hline
\end{tabular}

Sources: Statistics Portugal (INE); Portuguese Central Bank (Banco de Portugal)

(Integrated Economic Accounts Table (in Appendix); "from whom to whom matrices" for transactions D39 and D5-9 - see Table 2). 
Measuring the activity of European and African Countries using Social Accounting Matrices.

S.Santos

Table 7. SAM of Mozambique in 2007, with disaggregated factors of production and a part of the (domestic) institutions' current account (unit: $10^{6}$ meticais)

\begin{tabular}{|c|c|c|c|c|c|c|c|c|c|c|c|c|c|c|c|c|c|c|c|c|c|c|c|}
\hline \multicolumn{4}{|c|}{ Outlays (expenditures) } & \multicolumn{5}{|c|}{ PRODUCTION } & \multicolumn{13}{|c|}{ INSTITUTIONS } & \multirow[b]{3}{*}{$\begin{array}{c}\text { REST OF } \\
\text { THE } \\
\text { WORLD }\end{array}$} & \multirow{4}{*}{ TOTAL } \\
\hline & & & & \multirow[b]{2}{*}{ PRODUCTS } & \multirow[b]{2}{*}{ ACTIVITES } & \multicolumn{3}{|c|}{ FACTORS } & \multicolumn{6}{|c|}{ CURRENT ACCOUNT } & \multicolumn{6}{|c|}{ CAPITAL ACCOUNT } & \multirow[b]{2}{*}{ FNANCIAL } & & \\
\hline & & & & & & $\begin{array}{c}\text { Labour } \\
\text { (employees) }\end{array}$ & Own Assests & \multirow[t]{2}{*}{ Total } & Households & \begin{tabular}{|c|} 
Enterpises \\
(nonfinancial \\
corporations)
\end{tabular} & $\begin{array}{c}\text { Financial } \\
\text { comporations }\end{array}$ & Govemment & $\begin{array}{c}\text { NonProfitinsti- } \\
\text { tutionsServing } \\
\text { Households } \\
\text { (NPISH) } \\
\end{array}$ & Total & Households & $\begin{array}{l}\text { Enterprises } \\
\text { (nonfinancial } \\
\text { comporations) }\end{array}$ & $\begin{array}{c}\text { Financial } \\
\text { corporations }\end{array}$ & Govemment & $\begin{array}{c}\text { NonProfittnsti- } \\
\text { tutionsServing } \\
\text { Households } \\
\text { (NPISH) }\end{array}$ & Total & & & \\
\hline \multicolumn{4}{|c|}{ Incomes (receipts) } & 1 & 2 & 3 & 4 & & 5 & 6 & 7 & 8 & 9 & & 10 & 11 & 12 & 13 & 14 & & 15 & 16 & \\
\hline \multirow{5}{*}{$\begin{array}{l}z \\
0 \\
0 \\
0 \\
5 \\
0 \\
\frac{z}{2}\end{array}$} & PRODU & & 1 & 0 & 180731 & 0 & 0 & & 166398 & 0 & 0 & 24738 & 0 & 191137 & & & & & & 31784 & & 64146 & 467798 \\
\hline & ACTIVI & ITIES & 2 & 371384 & 0 & 0 & 0 & 0 & 0 & 0 & 0 & 0 & 0 & 0 & 0 & 0 & 0 & 0 & 0 & 0 & 0 & 0 & 371384 \\
\hline & $\frac{2}{2}$ & Labour (employees) & 3 & 0 & 49820 & 0 & 0 & & 0 & 0 & 0 & 0 & 0 & 0 & 0 & 0 & 0 & 0 & 0 & 0 & & 1505 & 51325 \\
\hline & 5 & Own Assets & 4 & 0 & 136101 & 0 & 0 & & 0 & 0 & 0 & 0 & 0 & of & 0 & 0 & 0 & 0 & 0 & 0 & d & 2748 & 138849 \\
\hline & 8 & Total & & 0 & 185920 & 0 & 0 & & 0 & to & 0 & 0 & 0 & of & 0 & 0 & 0 & to & 0 & 0 & o & 4253 & 190173 \\
\hline \multirow{13}{*}{ 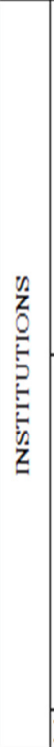 } & \multirow{6}{*}{ 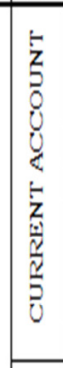 } & Households & 5 & 0 & 0 & 50331 & & & & & & & & & 0 & 0 & 0 & 0 & 0 & 0 & of & & \\
\hline & & $\begin{array}{l}\text { Enterprises } \\
\text { (nonfinancial corporations) }\end{array}$ & 6 & 0 & 0 & 0 & & & & & & & & & 0 & 0 & 0 & 0 & 0 & 0 & & & \\
\hline & & Financial corporations & 7 & 0 & 0 & 0 & & & & & & & & & 0 & 0 & 0 & 0 & 0 & 0 & & & \\
\hline & & Govemment & 8 & 16991 & 4732 & 0 & & & & & & & & & 0 & 0 & 0 & 0 & 0 & 0 & of & & \\
\hline & & $\begin{array}{l}\text { NonProfitinstitutionsSer } \\
\text { vingHouseholds(APISH) }\end{array}$ & 9 & 0 & 0 & 0 & & & & & & & & & 0 & 0 & 0 & 0 & 0 & 0 & & & \\
\hline & & Total & & 16991 & 4732 & 50331 & 122595 & 172925 & & & & & & & 0 & 0 & 0 & 0 & 0 & 0 & & & \\
\hline & \multirow{6}{*}{ 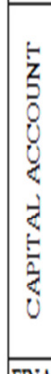 } & Households & 10 & 0 & 0 & 0 & 0 & 0 & & of & 0 & 0 & 0 & & & & & & & & & & \\
\hline & & $\begin{array}{l}\text { Enterprises } \\
\text { (nonfinancial corporations) }\end{array}$ & 11 & 0 & 0 & 0 & 0 & & 0 & 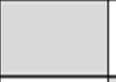 & 0 & 0 & 0 & & & & & & & & & & \\
\hline & & Financial corporations & 12 & 0 & 0 & 0 & 0 & & 0 & o) & & 0 & 0 & & & & & & & & & & \\
\hline & & Govermment & 13 & 0 & 0 & 0 & 0 & of & 0 & of & 0 & 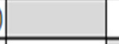 & 0 & & & & & & & & & & \\
\hline & & $\begin{array}{l}\text { NonProfithnstitutionsSer } \\
\text { vingHouseholds(NPISH) }\end{array}$ & 14 & 0 & of & 0 & 0 & & 0 & 0 & 0 & 0 & & & & & & & & & & & \\
\hline & & Total & & 0 & 0 & 0 & 0 & of & & & & & & 19083 & & & & & & & .1313 & & \\
\hline & \multicolumn{2}{|c|}{ FNANCIAL ACCOUNT } & 15 & 0 & 0 & 0 & of & d & 0 & o] & 0 & 0 & 0 & 0 & 0 & 0 & 0 & 0] & 0 & o & & & \\
\hline \multicolumn{3}{|c|}{ REST OF THE WORLD } & 16 & 79423 & 0 & 994 & 16254 & 17248 & & & & & & & & & & & & & & & \\
\hline \multicolumn{4}{|c|}{ TOTAL } & 467798 & 371384 & 51325 & 138849 & 190173 & & & & & & & & & & & & & & & \\
\hline
\end{tabular}

Sources: Instituto Nacional de Estatística de Moçambique; World Bank Databank by Country - Mozambique.

Notes: see the methodological details in Appendix B; the cells shaded in grey could not be filled in due to a lack of information. 


\subsection{Aggregates, indicators and balances}

As was seen above, practically all the transactions of the national accounts are covered by the SAM, so that macroeconomic aggregates, indicators and balances can be identified from it (see: the description of the cells or blocks in Tables 1 or 3; Tables 4 and 6 for the application to Portugal and Tables 5 and 7 for the application to Mozambique).

Gross Domestic Product at market prices $\left(\mathrm{GDP}_{\mathrm{pm}}\right)$, which is usually considered the main macroeconomic aggregate, can be calculated in the three known approaches:

- Production approach: $\mathrm{GDP}_{\mathrm{pm}}=\mathrm{P}-\mathrm{IC}+\mathrm{NTP}=\mathrm{t}_{a, \mathrm{p}}-\mathrm{t}_{\mathrm{p}, a}+\left(\mathrm{t}_{\mathrm{dic}, \mathrm{p}}+(\right.$ part of $\left.) \mathrm{t}_{\mathrm{rw}, \mathrm{p}}{ }^{5}\right)$;

- Expenditure approach: $\mathrm{GDP}_{\mathrm{pm}}=\mathrm{FC}+\mathrm{GCF}+\mathrm{Ex}-\mathrm{IM}=\mathrm{t}_{\mathrm{p}, \mathrm{dic}}+\mathrm{t}_{\mathrm{p}, \mathrm{dik}}+\mathrm{t}_{\mathrm{p}, \mathrm{rw}}-$ (part of) $\mathrm{t}_{\mathrm{rw}, \mathrm{p}}{ }^{5}$;

- Income approach: $\mathrm{GDP}_{\mathrm{pm}}=\mathrm{GAV}+\mathrm{NTP}+\mathrm{NTA}=\mathrm{t}_{\mathrm{f}, a}+\left(\mathrm{t}_{\mathrm{dic}, \mathrm{p}}+(\right.$ part of $\left.) \mathrm{t}_{\mathrm{rw}, \mathrm{p}}{ }^{5}\right)+\left(\mathrm{t}_{\mathrm{dic}, a}+\mathrm{t}_{\mathrm{rw}, a}{ }^{5}\right)$.

The Portuguese $\mathrm{GDP}_{\mathrm{pm}}$ in 2007 was $168737 * 10^{6}$ euros, which can be calculated from these three approaches as follows:

- Production approach: $\mathrm{GDP}_{\mathrm{pm}}=317058-171360+(22876+163)$;

- Expenditure approach: $\mathrm{GDP}_{\mathrm{pm}}=141615+38634+54514-66026$;

- Income approach: $\mathrm{GDP}_{\mathrm{pm}}=146564+(22876+163)+(230-1096)$.

In turn, in that same year, the Mozambican $\mathrm{GDP}_{\mathrm{pm}}$ was $207644 * 10^{6}$ meticais, which can be calculated from those same three approaches as follows:

- Production approach: $\mathrm{GDP}_{\mathrm{pm}}=371384-180731+16991$;

- Expenditure approach: $\mathrm{GDP}_{\mathrm{pm}}=191137+31784+64146-79423$;

- Income approach: $\mathrm{GDP}_{\mathrm{pm}}=185920+16991+4732$.

Domestic Product can be converted into National Product by adding the compensation of factors received from the rest of the world and deducting the compensation of factors and the net indirect taxes (on both products and production) sent to the rest of the world, when these exist. Thus, from the described cells of the basic SAM, GDP ${ }_{\mathrm{pm}}$ can be converted into Gross National Product at market prices $\left(\mathrm{GNP}_{\mathrm{pm}}\right)$ or Gross National Income $\left(\mathrm{GNI}_{\mathrm{pm}}\right)$, as follows: $\mathrm{GDP}_{\mathrm{pm}}+\mathrm{t}_{\mathrm{f}, \mathrm{rw}}-\mathrm{t}_{\mathrm{rw}, \mathrm{f}}-\mathrm{t}_{\mathrm{rw}, a}-$ (part of) $t_{r w, p}$. On the other hand, as the SAM directly provides Gross National Income at factor cost, this can also be calculated just by adding the net indirect taxes (on both products and production) received by domestic institutions: $t_{\text {dic, } f}+t_{\text {dic, }, p}+t_{\text {dic }, a}$. The corresponding amount for Portugal in 2007 is $163394 * 10^{6}$ euros, for which the underlying calculations are as follows: $\mathrm{GNP}_{\mathrm{pm}}=168737+13$ $056-(19333-1096+163) ; \mathrm{GNI}_{\mathrm{pm}}=140287+22876+230$. In the case of Mozambique, the

\footnotetext{
${ }^{5}$ Only for Portugal, in the case of our two applications.
} 
corresponding amount is $194648 * 10^{6}$ meticais, with the following corresponding calculations: $\mathrm{GNP}_{\mathrm{pm}}=207644+4253-17248 ; \mathrm{GNI}_{\mathrm{pm}}=172925+16991+4732$.

In turn, Gross aggregates can be converted into Net aggregates (and balances) by deducting the consumption of the fixed capital (transaction K1 of the National Accounts, which lies outside the basic SAM, as will be seen in Section 3.4, but is part of the Integrated Economic Accounts)

Disposable Income (Domestic or National; Gross or Net) is also very important and can be calculated by adding to $\mathrm{GNI}_{\mathrm{pm}}$ the net current transfers received by domestic institutions: $\mathrm{GNI}_{\mathrm{pm}}+$ $\left((\right.$ received $\left.) t_{d i c, d i c}+t_{d i c, r w}\right)-\left((\right.$ paid $\left.) t_{d i c, d i c}+t_{r w, d i c}\right)$. In our application to Portugal: $163394+(80940+$ $4841)-\left(80940+3128^{6}\right)=165107 * 10^{6}$ euros. In the case of Mozambique, although it was not possible to work on the current transfers block, since for this level of disaggregation the current transfers received by domestic institutions from domestic institutions ((received) $\left.t_{\text {dic,dic }}\right)$ and the current transfers paid by domestic institutions to domestic institutions ((paid) $t_{\text {dic,dic }}$ ) are equal, an approximate amount can be calculated using net current transfers $\left(t_{\text {dic,rw }}-t_{\text {rw,dic }}\right): 194648+15572$ $=210220 * 10^{6}$ meticais (see Appendix B).

Attention should be paid here to the fact that, especially in the case of Mozambique, where a considerable activity of all kinds is either not sold for cash or is not declared ${ }^{7}$, the above mentioned amounts of income "may tell us much less than it appears" - using the words of Seers (1952-1953: 160). Merely as an example in relation to this subject, an OECD study of the treatment of subsistence activities in national accounts concluded that "among the 48 developing countries covered, the share of non-monetary value added in total GDP ranges from over $40 \%$ for the poorer countries of Africa to $5 \%$ or less for the more advanced countries of Latin America and Southern Europe" (Blades, 1975: 391).

Gross Saving (S) and Net Lending or Borrowing (NLB) are given directly by the SAM, through $t_{\text {dik,dic }}$ and $t_{\text {dik,dif, }}$, respectively, which in the case of Portugal in 2007 are: 21473 and $15061 * 10^{6}$ euros. As explained in Subsection 3.1- k), the latter amount represents net borrowing. Mozambican Gross Saving is $19083 * 10^{6}$ meticais, while Net Lending is $1313 * 10^{6}$ meticais (see Appendix B).

The application for Portugal of all the described aggregates can be checked in the Integrated Economic Accounts Table, in Appendix A.

\footnotetext{
${ }^{6}$ In order to be completely consonant with the values of the national accounts, the direct purchases made abroad by the households are not considered here.

${ }^{7}$ A programme designed to measure the contribution of the informal sector to the National Accounts, beginning in July 2011, is available on the website of the Instituto Nacional de Estatística de Moçambique.
} 
It is also possible to calculate structural indicators of the functional and institutional distribution of generated income, as well as indicators of the use of disposable income.

In the functional distribution of generated income, the distribution of gross added value (at factor cost, GAV) among factors of production is given by the structure of the submatrix in the cell $\left(\mathrm{t}_{\mathrm{f}, a}\right)$ of the basic structure, with its level of detail depending on the disaggregation of the activities (column account) and of the factors of production (row account). Table 8 shows the results for the applications to Portugal and Mozambique.

Table 8. Portuguese and Mozambican functional distribution of the income generated in 2007 (in percentage terms)

\begin{tabular}{|l|r|c|}
\hline & Portugal & Mozambique \\
\hline $\begin{array}{l}\text { Factors of Production } \\
\text { (generated income = gross added value, at factor cost) }\end{array}$ & 56.5 & 26.7 \\
\hline $\begin{array}{l}\text { Labour } \\
\text { (employees) }\end{array}$ & 43.5 & 73.3 \\
\hline $\begin{array}{l}\text { Own assets } \\
\text { (employers and/or own-account workers; capital) }\end{array}$ & 100.0 & 100.0 \\
\hline Total & \\
\hline
\end{tabular}

Sources: Tables 6 and 7.

In the institutional distribution of generated income, the distribution of gross national income (at factor cost, GNI) is given by the structure of the submatrix in the cell $\left(t_{d i c, f}\right)$ of the basic structure. In this case, the level of detail will depend on the disaggregation of the factors of production (column account) and of the current account of the domestic institutions (row account). Table 9 shows the results of our application only for Portugal, since the required information for Mozambique is not available.

Table 9. Portuguese institutional distribution of the income generated in 2007 (in percentage terms)

\begin{tabular}{|l|c|c|c|}
\hline \multirow{2}{*}{} & \multicolumn{2}{|c|}{ Factors of Production } \\
\cline { 2 - 4 } & $\begin{array}{c}\text { Labour } \\
\text { (employees) }\end{array}$ & $\begin{array}{c}\text { Own assets } \\
\text { (employers and/or own- } \\
\text { account workers; capital) }\end{array}$ & Total \\
\hline $\begin{array}{l}\text { Institutions } \\
\text { (generated income = gross national income) }\end{array}$ & \multicolumn{2}{|c|}{} \\
\hline Households & 100.0 & 27.8 & 11.4 \\
\hline Non-financial corporations & & 10.3 & 4.2 \\
\hline Financial corporations & & -0.4 & -0.2 \\
\hline General government & & 1.6 & 0.7 \\
\hline Non-profit institutions serving households & & 100.0 & 100.0 \\
\hline Total & 100.0 & & 0.9 \\
\hline
\end{tabular}

Source: Table 6. 
As described above for the whole economy, the disposable income of the institutional sectors can be calculated in the same way, and then its distribution and use can also be studied - see Table 10.

Table 10. Portuguese distribution and use of disposable income among institutions and Mozambican total use of disposable income in 2007 (in percentage terms).

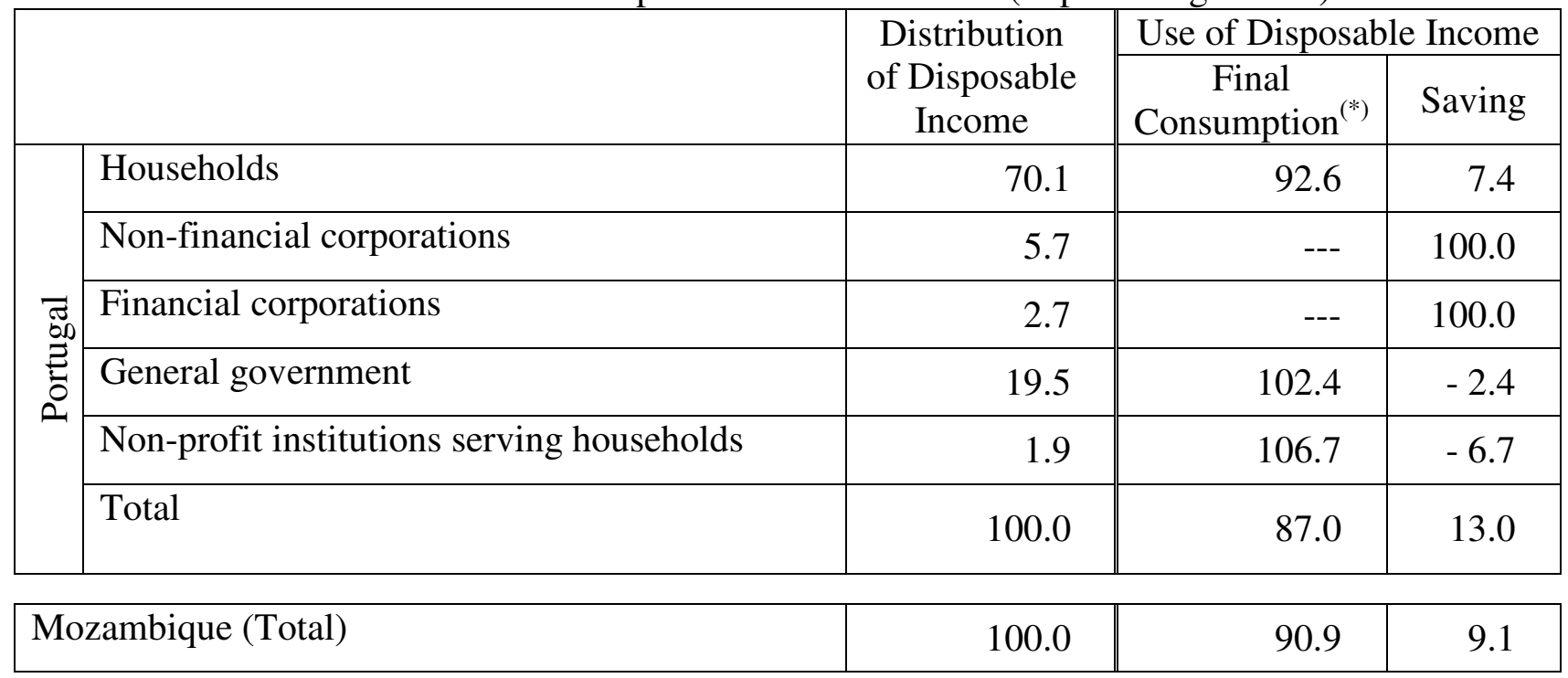

Sources: Tables 6 and 7.

${ }^{(*)}$ The expenditure (transaction P3 of the national accounts) and not the "actual" final consumption (transaction P4 of the national accounts), i.e. the amount really spent by each institution, although a part of the final consumption of the general government and all that of the NPISH will take the form of social transfers in kind (transaction D63 of the national accounts) and will include the "actual" final consumption of households.

Some additional data can allow for the study of other details, for instance per capita indicators with demographic information, despite the uncertainty of population estimates, especially for Mozambique, and the dangers of per capita estimates.

The main items in the balance sheets of the institutional sectors and of the rest of the world can be calculated from the respective rows and columns of the SAM. The former will be referred to as institutional balances and the latter as the balance of payments. In the former, the total balance is the net lending/borrowing (NLB) of the respective institution, with an opposite mathematical sign to the one registered in the SAM; the current balance is the respective gross saving (S); and the capital balance is the difference between the first and the second. Table 11 illustrates the institutional balances of the non-financial and financial corporations for Portugal in 2007. These balances cannot be calculated for Mozambique, due to a lack of information.

In turn, Tables 12 and 13 illustrate the rest of the world's balance, for Portugal and Mozambique respectively in 2007 . 
Measuring the activity of European and African Countries using Social Accounting Matrices.

S.Santos

Table 11. Institutional balances of Portuguese Non-Financial and Financial Corporations in 2007 (unit: $10^{6}$ euros)

\begin{tabular}{|c|c|c|c|c|c|c|c|c|}
\hline & \multicolumn{3}{|c|}{ Resources or Receipts (SAM rows) } & \multicolumn{3}{|c|}{ Uses or Expenditure (SAM columns) } & \multicolumn{2}{|c|}{ Balance } \\
\hline & & $\begin{array}{l}\text { Non-Financial } \\
\text { Corporations }\end{array}$ & $\begin{array}{c}\text { Financial } \\
\text { Corporations }\end{array}$ & & $\begin{array}{l}\text { Non-Financial } \\
\text { Corporations }\end{array}$ & $\begin{array}{c}\text { Financial } \\
\text { Corporations }\end{array}$ & $\begin{array}{l}\text { Non-Financial } \\
\text { Corporations }\end{array}$ & $\begin{array}{c}\text { Financial } \\
\text { Corporations } \\
\end{array}$ \\
\hline $\begin{array}{l}\text { 1. Current } \\
\text { Account (a) }\end{array}$ & & 18617 & 11948 & & 9144 & 7516 & 9473 & 4432 \\
\hline & $\begin{array}{l}\text { Gross National Income at } \\
\text { factor cost }\end{array}$ & 15972 & 5918 & Final Consumption & 0 & 0 & & \\
\hline & Net taxes on production & 0 & 0 & $\begin{array}{l}\text { Current transfers to } \\
\text { domestic institutions }\end{array}$ & 8914 & 7405 & & \\
\hline & Net taxes on products & 0 & 0 & $\begin{array}{l}\text { Current transfers to the } \\
\text { RW }\end{array}$ & 230 & 111 & & \\
\hline & $\begin{array}{l}\text { Current transfers from } \\
\text { domestic institutions }\end{array}$ & 2557 & 5957 & & & & & \\
\hline & $\begin{array}{l}\text { Current transfers from } \\
\text { the RW }\end{array}$ & 88 & 73 & & & & & \\
\hline $\begin{array}{l}\text { 2. Capital } \\
\text { Account }\end{array}$ & & -1110 & -52 & & 23125 & 1688 & -24235 & -1739 \\
\hline & $\begin{array}{l}\text { Capital transfers from } \\
\text { domestic institutions }\end{array}$ & 749 & 3 & $\begin{array}{l}\text { Gross Capital } \\
\text { Formation }\end{array}$ & 23003 & 1683 & & \\
\hline & $\begin{array}{l}\text { Capital transfers from } \\
\text { the RW }\end{array}$ & - 1859 & -55 & $\begin{array}{l}\text { Capital transfers to } \\
\text { domestic institutions }\end{array}$ & 22 & 4 & & \\
\hline & & & & $\begin{array}{l}\text { Capital transfers to the } \\
\text { RW }\end{array}$ & 100 & 0 & & \\
\hline $3=1+2(b)$ & & 17507 & 11896 & & 32269 & 9204 & -14762 & 2692 \\
\hline
\end{tabular}

Source: Table 6 (rows/columns 6, 7, 11 and 12)

(a) Balance $=$ Gross saving

(b) Balance $=-$ Net lending $(+) /$ borrowing (-) 
Measuring the activity of European and African Countries using Social Accounting Matrices.

S.Santos

Table 12. Rest of the World's Balance for Portugal in 2007 (unit: $10^{6}$ euros)

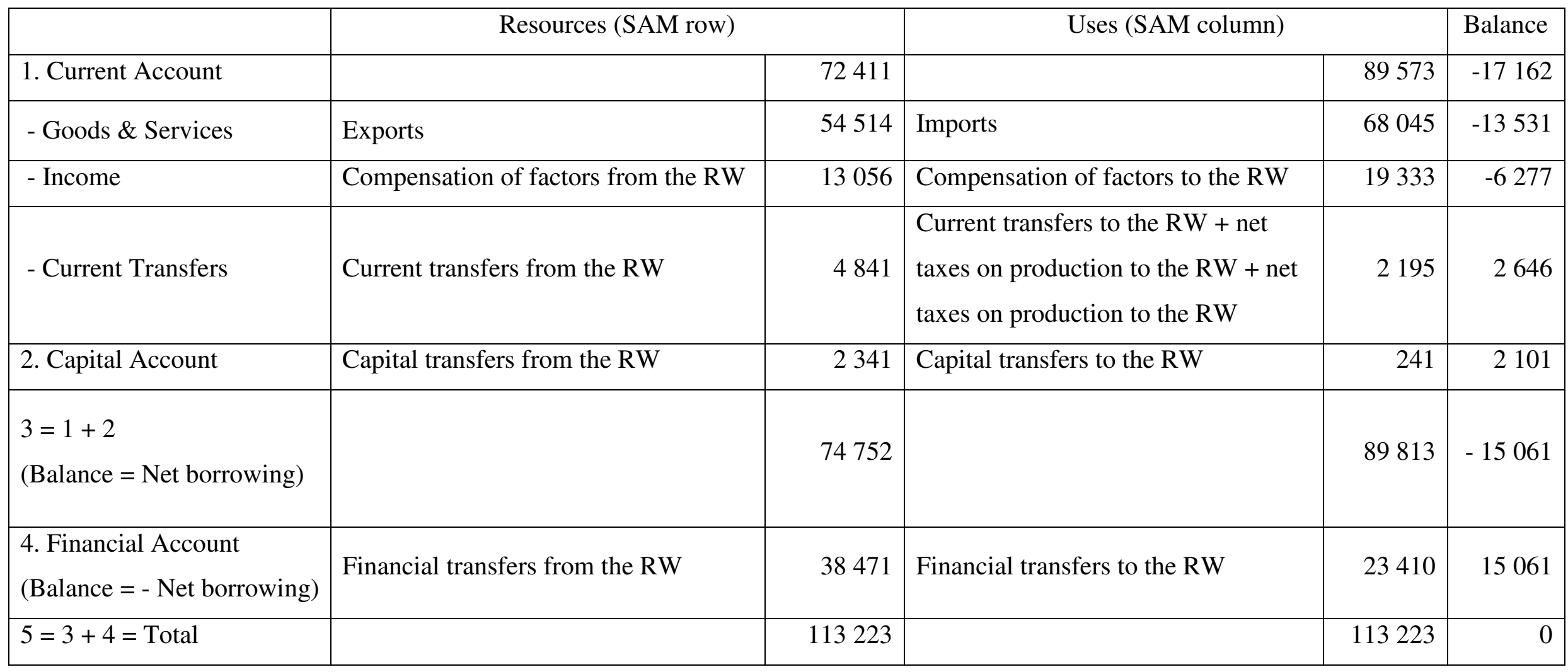

Source: Table 6 (row/column 16) 
Measuring the activity of European and African Countries using Social Accounting Matrices.

S.Santos

Table 13. Rest of the World's Balance for Mozambique in 2007 (unit: $10^{6}$ meticais)

\begin{tabular}{|c|c|c|c|c|c|}
\hline & \multicolumn{2}{|l|}{ Resources (SAM row) } & \multicolumn{2}{|l|}{ Uses (SAM column) } & Balance \\
\hline 1. Current Account & & & & & -12700 \\
\hline - Goods \& Services & Exports & 64146 & Imports & 79423 & -15277 \\
\hline - Income & Compensation of factors from the RW & 4253 & Compensation of factors to the $\mathrm{RW}$ & 17248 & -12995 \\
\hline - Current Transfers & Current transfers from the RW & & Current transfers to the RW & & 15572 \\
\hline $\begin{array}{l}\text { 4. Financial Account } \\
\text { (Balance }=- \text { Net Lending) }\end{array}$ & Financial transfers from the RW & & Financial transfers to the RW & & -1313 \\
\hline $5=3+4=$ Total & & & & & 0 \\
\hline
\end{tabular}

Sources: Table 7 (row/column 16); World Bank Databank by Country - Mozambique.

Notes: see the methodological details in Appendix B; the cells shaded in grey could not be filled in due to a lack of information. 


\subsection{Examples of policy-type questions that can be addressed using a SAM}

From what was seen above, by covering practically all the representative nominal flows of the measured part of the country's activity (if it is assumed that this is sufficiently representative), the SAM can be used to support the policy decision process in several ways, given the flexibility of the described basic structure and the possibilities of specification of various aspects of the underlying systems.

For example, under the scope of the social policy measures, we may want to work with specific flows in which government and households intervene directly, namely the current transfers between them both. Let us consider the case of the direct taxes on income, paid by the households to the government, and the case of the social benefits, paid by the government to the households. The identification of the absolute and relative importance of these flows in the corresponding institutional balances may be a first step. Tables 14 and 15 show the application to Portugal - the same will not be possible for Mozambique due to a lack of information by institutional sector. On the other hand, comparisons with macroeconomic aggregates and some SAM values can complement that knowledge. For instance, in our application to Portugal, the current taxes on income and wealth, etc., paid by households to the government represent $6.3 \%$ of the aggregate income of the former (the row/column total of its current account); or, alternatively, the benefits other than social transfers in kind, paid by the government to the households, represent $21.1 \%$ of the households' disposable income.

From here, different scenarios can be studied using SAM-based model(s). The distributional effects of social policy measures directed to specific flows (for example, the direct taxes on income or the social benefits) can be studied not only at the level of the institutional sectors involved, but also at the level of the part of the country's activity that is quantified by the SAM (Santos, 2010, performs related experiments). 


\section{Measuring the activity of European and African Countries using Social Accounting Matrices.}

S.Santos

Table 14. Institutional Balance of Portuguese Government in 2007 and the relative importance of the current taxes on income, wealth, etc., (transactions D5) received from households and of the social benefits other than social transfers in kind (transaction D62) paid to the households.

\begin{tabular}{|c|c|c|c|c|c|c|c|}
\hline & \multicolumn{3}{|c|}{ Resources or Receipts (SAM row) } & \multicolumn{3}{|c|}{ Uses or Expenditure (SAM column) } & \multirow{2}{*}{$\begin{array}{c}\text { Balance } \\
10^{6} \text { euros }\end{array}$} \\
\hline & & $10^{6}$ euros & $\begin{array}{l}\text { Relative } \\
\text { importance of } \\
\text { D5 in.. (\%) }\end{array}$ & & $10^{6}$ euros & $\begin{array}{c}\text { Relative } \\
\text { importance of } \\
\text { D62 in.. (\%) }\end{array}$ & \\
\hline \multirow[t]{6}{*}{$\begin{array}{l}\text { 1. Current } \\
\text { Account (a) }\end{array}$} & & 60723 & 16.0 & & 61490 & 39.8 & -767 \\
\hline & $\begin{array}{l}\text { Gross National Income at factor } \\
\text { cost }\end{array}$ & -230 & & Final Consumption & 32999 & & \\
\hline & Net taxes on production & 230 & & $\begin{array}{l}\text { Current transfers to domestic } \\
\text { institutions } \\
\text { - D62 paid to the households }\end{array}$ & $\begin{array}{l}26905 \\
24469\end{array}$ & 90.9 & \\
\hline & Net taxes on products & 22876 & & Current transfers to the RW & 1586 & & \\
\hline & $\begin{array}{l}\text { Current transfers from domestic } \\
\text { institutions } \\
\text { - D5 received from the households }\end{array}$ & $\begin{array}{r}37328 \\
9689 \\
\end{array}$ & 26.0 & & & & \\
\hline & Current transfers from the RW & 518 & & & & & \\
\hline \multirow[t]{4}{*}{$\begin{array}{l}\text { 2. Capital } \\
\text { Account }\end{array}$} & & 1215 & & & 5225 & & -4010 \\
\hline & $\begin{array}{l}\text { Capital transfers from domestic } \\
\text { institutions }\end{array}$ & 34 & & Gross Capital Formation & 4113 & & \\
\hline & Capital transfers from the RW & 1181 & & $\begin{array}{l}\text { Capital transfers to domestic } \\
\text { institutions }\end{array}$ & 1084 & & \\
\hline & & & & Capital transfers to the RW & 28 & & \\
\hline $3=1+2(b)$ & & 61938 & 15.6 & & 66715 & 36.7 & -4777 \\
\hline
\end{tabular}

Source: Table 6 (rows/columns 8 and 13) and "from whom to whom matrices"- Statistics Portugal (INE)

(a) Balance $=$ Gross saving

(b) Balance $=-$ Net lending $(+) /$ borrowing $(-)$ 


\section{Measuring the activity of European and African Countries using Social Accounting Matrices.}

S.Santos

Table 15. Institutional Balance of Portuguese Households in 2007 and the relative importance of the current taxes on income, wealth, etc., (transactions D5) paid to the government and of the social benefits other than social transfers in kind (transaction D62) received from the government.

\begin{tabular}{|c|c|c|c|c|c|c|c|}
\hline & \multicolumn{3}{|c|}{ Resources or Receipts (SAM row) } & \multicolumn{3}{|c|}{ Uses or Expenditure (SAM column) } & \multirow{2}{*}{$\begin{array}{l}\text { Balance } \\
10^{6} \text { euros }\end{array}$} \\
\hline & & $10^{6}$ euros & $\begin{array}{l}\text { Relative } \\
\text { importance of } \\
\text { D62 in.. }(\%)\end{array}$ & & $10^{6}$ euros & $\begin{array}{c}\text { Relative } \\
\text { importance of } \\
\text { D5 in.. }(\%)\end{array}$ & \\
\hline $\begin{array}{l}\text { 1. Current } \\
\text { Account (a) }\end{array}$ & & 154567 & 15.8 & & 146015 & 6.6 & 8551 \\
\hline & Gross National Income at factor cost & 117680 & & Final Consumption & 105201 & & \\
\hline & $\begin{array}{l}\text { Current transfers from domestic } \\
\text { institutions } \\
\text { - D62 received from the government }\end{array}$ & $\begin{array}{l}32725 \\
24469 \\
\end{array}$ & 74.8 & $\begin{array}{l}\text { Current transfers to domestic } \\
\text { institutions } \\
\text { - D5 paid to the government }\end{array}$ & $\begin{array}{r}37594 \\
9689 \\
\end{array}$ & 25.8 & \\
\hline & Current transfers from the RW & 4162 & & Current transfers to the RW & 3221 & & \\
\hline $\begin{array}{l}\text { 2. Capital } \\
\text { Account }\end{array}$ & & 3125 & & & 9411 & & -6286 \\
\hline & $\begin{array}{l}\text { Capital transfers from domestic } \\
\text { institutions }\end{array}$ & 77 & & Gross Capital Formation & 9287 & & \\
\hline & Capital transfers from the RW & 3048 & & $\begin{array}{l}\text { Capital transfers to domestic } \\
\text { institutions }\end{array}$ & 11 & & \\
\hline & & & & Capital transfers to the RW & 113 & & \\
\hline $3=1+2(b)$ & & 157691 & 15.5 & & 155426 & 6.2 & 2265 \\
\hline
\end{tabular}

Source: Table 6 (rows/columns 5, and 10) and "from whom to whom matrices"- Statistics Portugal (INE)

(a) Balance $=$ Gross saving

(b) Balance $=-$ Net lending $(+) /$ borrowing $(-)$ 


\section{Going beyond the basic structure}

In order to improve the snapshot given by the SAM, as described above, some rearrangements could be made to the described cell contents and/or some zero cells could be filled in. This can be done either within and/or outside the scope of the SNA

a) Within the scope of the SNA, the following topics are examples of rearrangements that could be made to the described cell contents (the described cells can be identified in Tables 1 or 3 ), in order to avoid the existence of negative cells in the SAM. This would help to improve its definition (incomings in rows and outgoings in columns) and facilitate the application of certain balancing methods, whenever necessary.

a.1) Instead of working with net indirect taxes, it is possible to work with taxes and subsidies separately. The taxes on products and on production could be recorded in the abovedescribed NTP $\left(\mathrm{t}_{\mathrm{dic}, \mathrm{p}} ; \mathrm{t}_{\mathrm{rw}, \mathrm{p}}\right)$ and NTA $\left(\mathrm{t}_{\mathrm{dic}, a} ; \mathrm{t}_{\mathrm{rw}, a}\right)$ blocks, respectively. The subsidies on products could be recorded in cells $t_{p, d i c}$ and $t_{p, r w}$. The subsidies on production would then be recorded in cells $t_{a, d i c}$ and $t_{a, r w}$.

a.2) The net lending or borrowing (NLB), which, in the SAM's capital account, is considered as a component of investment funds, not required or required to cover aggregate investment, could be recorded in cells $t_{\text {dik,dif }}$, in the case of net borrowing, and in cells $t_{\text {dif,dik }}$, in the case of net lending. Thus, if there is net borrowing, we have a financing requirement that is covered by financial transactions (from the rest of the world, since the national funds are not sufficient), i.e. a resource of the capital account (row) and a use of the financial account (column). If there is net lending, we have a financing capacity that will be absorbed by financial transactions (to the rest of the world, since there is an excess of national funds), i.e. a resource of the financial account (row) and a use of the capital account (column).

b) Still working within the scope of the SNA, some new data could be considered, either in addition to other data or as possible replacements for these figures.

b.1) The consumption of fixed capital could be included in $t_{p, d i k}$.

b.2) The production of the institutional sectors could be included in $t_{\text {dic,p }}$. In the basic structure, production is recorded in cells $t_{a, p}$.

b.3) The intermediate consumption of the institutional sectors could be included in $t_{\text {,dic }}$. In the basic structure, intermediate consumption is recorded in cells $\mathrm{t}_{\mathrm{p}, a}$. 
c) Outside the scope of the SNA, working either within or outside the framework of the satellite accounts, the inclusion of the following aspects could be considered ${ }^{8}$.

c.1) The expansion of the production boundary, for example recording the services that households deliver to themselves, associated or not with a subsistence output (so common in African countries) $)^{9}$. The extension to unpaid household activity is presented by the SNA as an example of satellite accounts (ISWGNA, 2008: 542-543). On the other hand, the SNA dedicates its Chapter 25 to the consideration of informal aspects of the economy (ISWGNA, 2008: 471-482). In these cases, it is suggested that a possible distinction should be made between income in cash and in kind.

c.2) The (re)analysis of the imputations; the underlying methodologies and possible adjustments.

c.3) The rethinking of the way in which the factors of production are worked upon and the possible consideration of natural resources and their relationship with the country's activity. The extension to environmental accounting is presented by the SNA as an example of satellite accounts (ISWGNA, 2008: 534-538).

c.4) Stocks of capital and wealth.

c.5) Demography and the activity of the population of working age, their time use, skills, etc.

It is known that the implementation and study of some of these topics, especially those referred to in subsection c), could become valuable research projects, and that, in fact, some of them are already part of the SNA's research agenda. However, the aim here is to show that, although the SAM (especially when based on the SNA) can be a very complete and credible measurement tool, there is still much that can be done to improve it.

\section{Concluding remarks}

Together, the United Nations System of National Accounts (SNA) is flexible enough and the Social Accounting Matrix (SAM)-based approach versatile enough to quantitatively represent the country's activity with some validity. From that representation, underlying systems can be

\footnotetext{
${ }^{8}$ Some of the aspects referred to in this paragraph were also referred to by Pyatt (1991a) when he argued in favour of a radical revision of the 1968 SNA, and by Round (2003) when he discussed the problematic compilation issues under the scope of the 1993 SNA.

${ }^{9}$ Following Seers (1952-1953), the treatment of the subsistence activities is identified, in Lury (1964), as a special problem which arises when the concepts and methods of national accounts calculation, as recommended by the United Nations, had to be used in Africa.
} 
identified and worked upon in order to support different studies in several areas, as well as the policy decision process.

It is proposed that the work on the sectors of production should be undertaken in conjunction with the institutional sectors, using the national accounts as the base source of information. This will make it possible to work simultaneously on the following items: some specificities and results of the production process; the distribution and redistribution of income; the redistribution of wealth; investment, its financing and the debt levels of the institutional sectors and the whole economy. It will also make it possible to work with a network of linkages and interactions, helping to identify interdependencies that cannot otherwise be detected.

The SNA and some countries and groups of countries have been undertaking important work in measuring a country's activity, as exhaustively and accurately as possible. Such information should be used in the best possible way. However, as far as the SNA is concerned, some related aspects should be considered and studied, namely those that were addressed in section 4.c). In turn, the performance of those countries or groups of countries that adopt/adapt the SNA has not been uniform, as is partly illustrated by our two applications.

The application to Portugal, a member of the European group, covers a significant part of what is defined by the SNA, although it almost completely ignores the financial accounts of institutional sectors, giving less importance to the "from whom to whom" transactions between institutional sectors, within the scope of their current and capital accounts.

The application to Mozambique shows that the institutional part is almost completely ignored, which therefore means that all the important aspects that the corresponding current, capital and financial accounts can quantify, namely the distribution, use and redistribution of income, are also ignored.

Thus, in both cases, the above-mentioned support that the SAM can provide to studies in several areas or to the policy decision process is open to question - as illustrated by section 3.4, in the area of social policy and in the case of Mozambique.

A SAM-based approach incorporates two versions of the SAM. A numerical version describes the activity of a society empirically, in which each cell has a specific numerical value, with the sums of the rows being equal to the sums of the columns. In turn, an algebraic version describes that same activity theoretically. Each cell of the latter version contains algebraic expressions that, together with those of all the other cells, make up a SAM-based model, the calibration of which involves a replication of the numerical version. References for the latter were given and the construction of the 
former from the SNA was proposed. From that proposal the following possibilities were highlighted:

- Multi-period and dynamic analysis, since national accounts are published regularly.

- Identification of the network of nominal links existing within the (socio-)economic system, allowing for the particularisation of regions, products (goods and services), activities (industries), institutions or sets of institutions (households, enterprises, government), etc.

- Study of the processes of production and trade, as well as the distribution, redistribution and accumulation of income.

- Evaluation of the impacts of alternative policy measures and the consequent policy decision, i.e. the processes of decision-making and decision-taking.

- Better use of the quantitative information available, since the SNA has developed national accounts that are increasingly consistent and in harmony with all other statistics.

However, both within and outside the scope of the SNA, there are several important aspects that still need to be completed, especially when work has to be undertaken in countries such as the African ones where a substantial part of their activities is not marketed and/or not measured. Some rearrangements can be made to the described cell contents and/or some zero cells can be filled in. Coverage of those aspects would improve the numerical version of the SAM, proposed in this paper and the possible algebraic versions derived from it.

Our work here was carried out with the aim of producing a SAM, adapted to the SNA, that is not only capable of covering everything that can be measured according to its criteria, but also has room for the inclusion of aspects that have not yet been measured but may need to be measured in the future. As far as the latter question is concerned, we are thinking mainly about the non-marketed parts of a country's activity, which is why we suggest that the first approach to this subject should consist of making a distinction between income in cash and in kind.

By using a SAM-based approach, with a consistent and credible numerical version and a corresponding well-defined algebraic version of a SAM, it will be possible to cover important aspects of the activity of the countries and improve the knowledge of the underlying systems. A SAM that is suitably designed to address a specific problem or set of problems can result in a fully interlinked macro-model, which can play an invaluable role in providing quantitative support for several studies, as well as in the policy decision process. 


\section{References}

Arndt, C. et al., "Social Accounting Matrices for Mozambique 1994 and 1995", TMD (Trade and Macroeconomics Division) Discussion Paper No. 28, International Food Policy Research Institute, Washington, D.C., 1998.

Blades, D.W., "Subsistence activities in the national accounts of developing countries with special reference to Latin America", Review of Income and Wealth, 21 (4), 391-410, December 1975.

Inter-Secretariat Working Group on National Accounts - ISWGNA, System of National Accounts (2008 SNA), United Nations Statistics Division and the United Nations regional commissions, New York; International Monetary Fund - IMF, Washington, DC; World Bank, Washington, DC; Organisation for Economic Cooperation and Development - OECD, Paris; Statistical Office of the European Communities - Eurostat, Brussels/Luxembourg, 2008.

Keuning S. and Ruijter W., "Guidelines to the construction of a Social Accounting Matrix", Review of Income and Wealth, 34, 71-100, 1988.

Lury, D.A., "National Accounts in Africa", The Journal of Modern African Studies, vol.2 (1), 99110, March 1964.

Pyatt, G., "Some Early Multiplier Models of the Relationship between Income Distribution and Production Structure”,. Economic Systems Research, 13, 139-163, 2001.

Pyatt, G., "Some Relationships between T-Accounts, Input-Output Tables and Social Accounting Matrices”, Economic Systems Research, 11, 365-387, 1999.

Pyatt, G., "Fundamentals of Social Accounting", Economic Systems Research, 3, 315-341, 1991.

Pyatt, G., "SAMs, the SNA and National Accounting Capabilities", Review of Income and Wealth, 37, 177-198, 1991a.

Pyatt, G., "Commodity Balances and National Accounts: a SAM Perspective", Review of Income and Wealth, 31, 155-169, 1985.

Pyatt, G., “A SAM Approach to Modeling”, Journal of Policy Modeling, 10, 327-352, 1988.

Pyatt, G. and Roe, A., Social Accounting for Development Planning with Special Reference to Sri Lanka, Cambridge University Press, Cambridge-UK, 1977.

Pyatt, G. and Round, J., "Accounting and Fixed Price Multipliers in a Social Accounting Matrix Framework". in: G. Pyatt, and J. Round, (coord.), Social Accounting Matrices. A Basis for Planning, 52-69, A World Bank Symposium, World Bank, 1985. 
Roe. A., "Asymmetries between Rich and Poor Countries in Financial Crisis Responses: the Need for Flow-of-Funds Approach”, Economic Systems Research, 15, 233-257, 2003.

Round, J., "Constructing SAMs for Development Policy Analysis: Lessons Learned and Challenges Ahead", Economic Systems Research, 15, 161-183, 2003.

Round, J., "The Structure of the European Economy: a SAM Perspective”, in: J. Round, (ed.), The European Economy in Perspective. Essays in Honour of Edward Nevin, 59-83, University of Wales Press, Cardiff, 1994.

Round, J., “A SAM for Europe: Problems and Perspectives”, Economic Systems Research, 3, 249268, 1991.

Santos S., "A quantitative approach to the effects of social policy measures. An application to Portugal, using Social Accounting Matrices”, EERI (Economics and Econometrics Research Institute) RP (Research Papers) 2010/33; MPRA (Munich Personal RePEc Archive) Paper No. $23676,2010$.

Santos S., From the System of National Accounts (SNA) to a Social Accounting Matrix (SAM)Based Model. An Application to Portugal, Edições Almedina, Coimbra-Portugal, 2009.

Santos S., "Macro-SAMs for Modelling Purposes. An Application to Portugal in 2003", Working Paper No. 17/2007/ Department of Economics/Research Unit on Complexity and Economics, ISEG-UTL, 2007.

Santos S., "Modelling Economic Circuit Flows in a Social Accounting Matrix Framework. An Application to Portugal", Applied Economics, 39, 1753-1771, 2007a.

Santos S., "Portuguese net borrowing and the government budget balance. A SAM approach", Journal of Policy Modeling, 26, 703-717, 2004.

Seers, D., "The Role of Income Estimates in the Statistical Policy of an Underdeveloped Area", The Review of Economic Studies, Vol.20 (3), 159-168, 1952-1953.

Tarp, F. et al., "Facing the Development Challenge in Mozambique. An Economy-wide Perspective", Research Report No. 126, International Food Policy Research Institute, Washington, D.C., 2002. 
Measuring the activity of European and African Countries using Social Accounting Matrices. S.Santos

Appendix A. Integrated Economic Accounts Table for Portugal in 2007 (unit: $10^{6}$ euros)

\begin{tabular}{|c|c|c|c|c|c|c|c|c|c|c|c|c|}
\hline \multicolumn{13}{|c|}{$\begin{array}{l}\text { Curkatat aceswats } \\
\text { dses }\end{array}$} \\
\hline \multirow{2}{*}{\multicolumn{2}{|c|}{ antowat }} & \multirow[b]{2}{*}{ 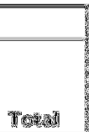 } & \multirow[b]{2}{*}{ 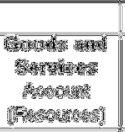 } & \multirow{2}{*}{ 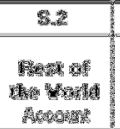 } & 5. & 8 & $5 \%$ & 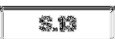 & 2.2. & 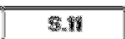 & \multirow{2}{*}{\multicolumn{2}{|c|}{ 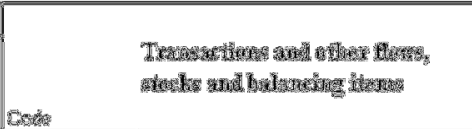 }} \\
\hline & & & & & 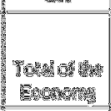 & 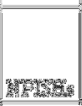 & Honstastat & 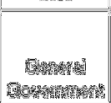 & 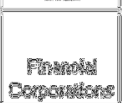 & 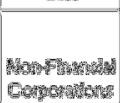 & & \\
\hline \multirow{9}{*}{\multicolumn{2}{|c|}{ 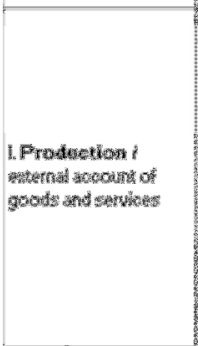 }} & 6045 & 8045 & & & & & & & & 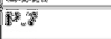 & 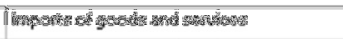 \\
\hline & & 54514 & & 54514 & & & & & & & P.6 & Exports of goods and services \\
\hline & & 317058 & 317058 & & & & & & & & P.1 & Output of goods and services \\
\hline & & 171360 & & & 171360 & 2238 & $1266 ?$ & 7048 & 5207 & 144201 & P.2 & Intermediate consumption \\
\hline & & 23039 & 2300 & & 23099 & & & & & & 0240.31 & 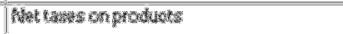 \\
\hline & & 168 พ & & & 16437 & 267 & 39 383 & 23131 & IIt 97 & 7928 & E.tgiderg & 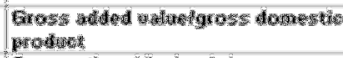 \\
\hline & & 28.351 & & & 263 & 551 & 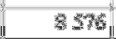 & 325 & $6 \pi$ & 25283 & $x+1$ & Consumption of fored capital \\
\hline & & $140: 34 \times$ & & & 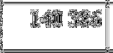 & 1\%25 & 裳焦 & 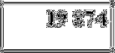 & $10 \mathrm{sen}$ & 萦62x & 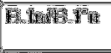 & 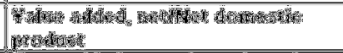 \\
\hline & & 24 & & 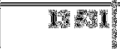 & & & & & & & E.T & 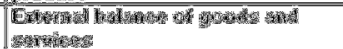 \\
\hline \multirow{10}{*}{ 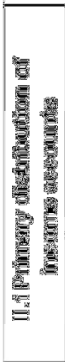 } & \multirow{7}{*}{ 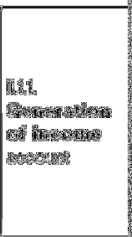 } & 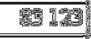 & & 34 & 烈 & 3) & 56 & 21371 & 4 & 35 & D.ti & 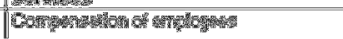 \\
\hline & & 202 & & & 202 & 4 & Mas & & 䎑 & 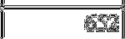 & E. & 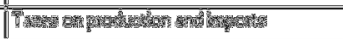 \\
\hline & & $-2 a^{2}$ & & & 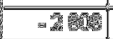 & $=1$ & -756 & $=-3$ & $\Rightarrow$ & $=9$ & W & Fing \\
\hline & & 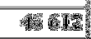 & & & 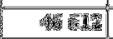 & 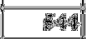 & 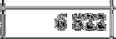 & 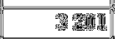 & 弱络1: & 繁第 & 2xy & 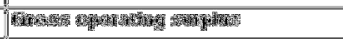 \\
\hline & & 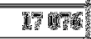 & & & inger & & 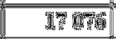 & & & & EDy & 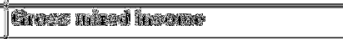 \\
\hline & & 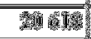 & & & 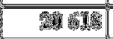 & -2 & 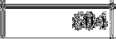 & $=$ 霸 & 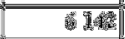 & Ding & Els & 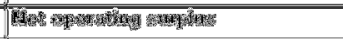 \\
\hline & & (4) & & & MWM & & 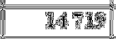 & & & & 125x & 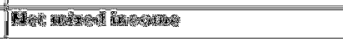 \\
\hline & \multirow{3}{*}{ 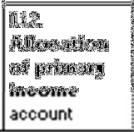 } & 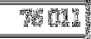 & & 1250 & 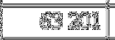 & 8 & 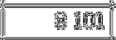 & 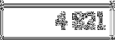 & 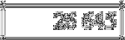 & 24 . & Bu & Fas; \\
\hline & & Whath & & & 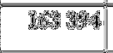 & 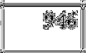 & Lif of & 287 & 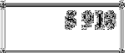 & Ifin & Exigy & 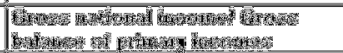 \\
\hline & & 135043 & & & 135043 & 395 & 109104 & 19620 & 5245 & 679 & B.5n & $\begin{array}{l}\text { Net national încomer Net baíance } \\
\text { of primary incomes }\end{array}$ \\
\hline \multirow{6}{*}{\multicolumn{2}{|c|}{$\begin{array}{l}\text { 11.2. Secondary } \\
\text { distribution income } \\
\text { account }\end{array}$}} & 16112 & & 21 & 16092 & 6 & 9717 & 21 & 1399 & 4949 & D.5 & Current taxes on income, wealth, etc \\
\hline & & 25264 & & 71 & 25193 & & 25193 & & & & D.61 & Social contributions \\
\hline & & 29742 & & 48 & 29694 & 49 & 48 & 24611 & 3271 & 1715 & D.62 & $\begin{array}{l}\text { Social benefits other than social transfers } \\
\text { in kind }\end{array}$ \\
\hline & & 17222 & & 4702 & 12520 & 67 & 3837 & 3859 & 2278 & 2480 & D.7 & Other current transfers \\
\hline & & 165107 & & & 165107 & 3199 & 115202 & 32232 & 5000 & 9473 & B.6g & Gross disposable income \\
\hline & & 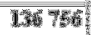 & & & 136 7. & 264 & 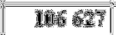 & Nys & 4327 & 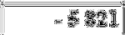 & $\overline{\mathrm{e}} \overline{\mathrm{G}}$ & Het disposable hocoma \\
\hline \multirow{3}{*}{\multicolumn{2}{|c|}{ 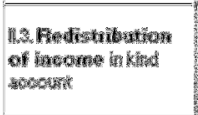 }} & 22142 & & & 22145 & 344 & & 1872 & & & Des & 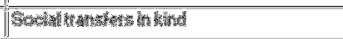 \\
\hline & & $16 \% 107$ & & & I6G 107 & $=316$ & 1973 & 1354 & Gon & 946 & Fizy & 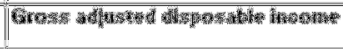 \\
\hline & & 136758 & & & 138756 & $=767$ & 12: 76 & I0 247 & $43 n 7$ & 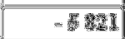 & Extras & 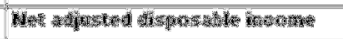 \\
\hline \multirow{8}{*}{\multicolumn{2}{|c|}{ 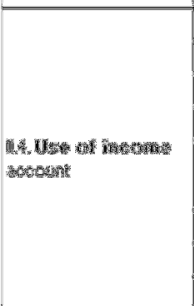 }} & 16. 197? & & & 18E 16T & 3159 & IIStos & 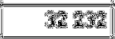 & 沕 000 & 54 & E.s.g & 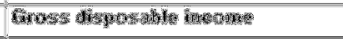 \\
\hline & & $130 \mathrm{756}$ & & & $136 x^{7}$ & 数程 & 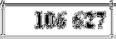 & 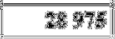 & 437 & 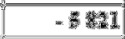 & E.S. & 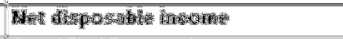 \\
\hline & & 145694 & & & 143634 & 9415 & 10720 & 32909 & & & Pu & 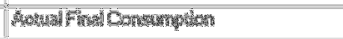 \\
\hline & & 146 694 & & & 143634 & & 220309 & 4272 & & & F. & 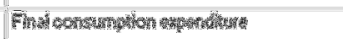 \\
\hline & & 369 & & & șep & & & & 509 & & 0.6 & 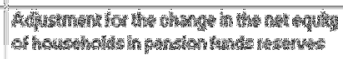 \\
\hline & & 2I. $47 \%$ & & & $2 \pi+4$ & $=2$ & sy & $-7 \sqrt{7}$ & 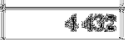 & 967 & B) & 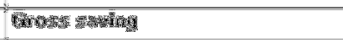 \\
\hline & & 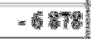 & & & -637 & $-\frac{76 \%}{4}$ & $-x$ & -4024 & 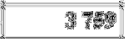 & 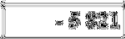 & Es & 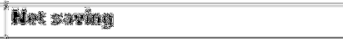 \\
\hline & & MTH & & 17140 & & & & & & & 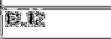 & 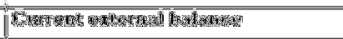 \\
\hline
\end{tabular}

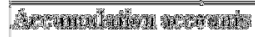

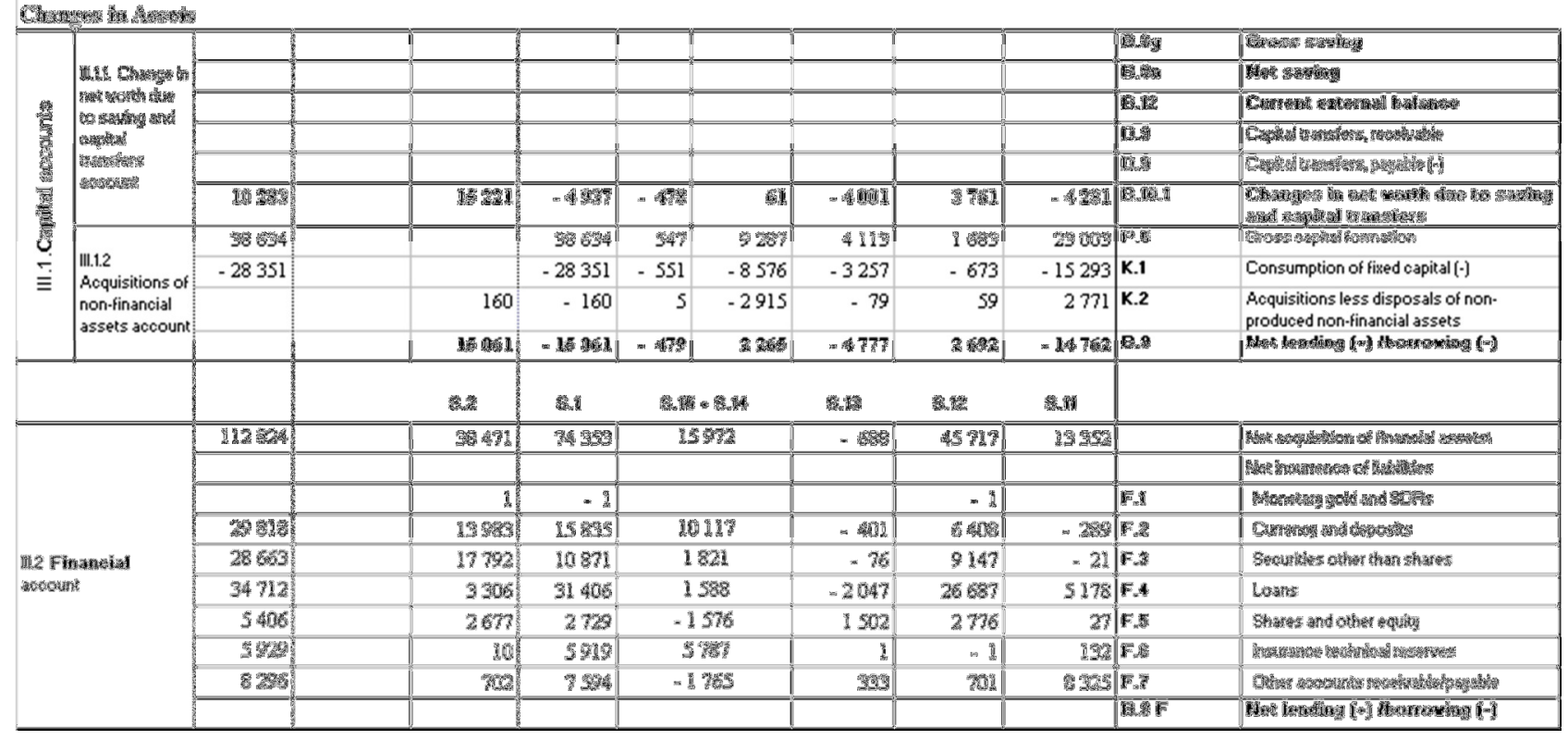


Measuring the activity of European and African Countries using Social Accounting Matrices. S.Santos

Appendix A. Integrated Economic Accounts Table for Portugal in 2007 (unit: $10^{6}$ euros) (continued) Resowuces

\begin{tabular}{|c|c|c|c|c|c|c|c|c|c|c|c|c|}
\hline & & 8.11 & 5 & 矣䊁 & S.6\% & 然糟 & 5. & 5.2 & & & \multirow{2}{*}{\multicolumn{2}{|c|}{ Show }} \\
\hline Exis: & 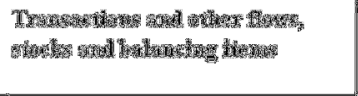 & 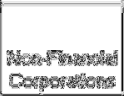 & 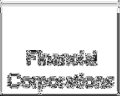 & 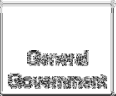 & 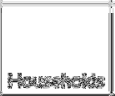 & 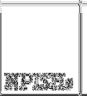 & Tos & 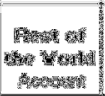 & 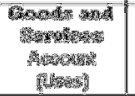 & Twes & & \\
\hline Fra & 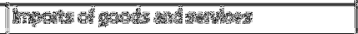 & & & & & & & 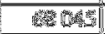 & & 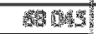 & \multirow{5}{*}{\multicolumn{2}{|c|}{ 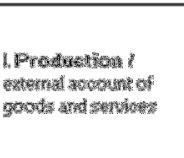 }} \\
\hline 政 & 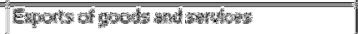 & & & & & & & & 9454 & 54514 & & \\
\hline Fit & 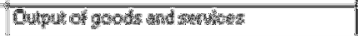 & 228729 & 16185 & 30179 & 4050 & 4915 & 312058 & & & 317058 & & \\
\hline$\beta=2$ & 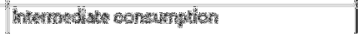 & & & & & & & & 171360 & 171568 & & \\
\hline D.2I-D.3I & 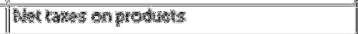 & & & & & & 23099 & & & 29 t99 & & \\
\hline 焉. & 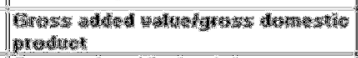 & 7928 & 1678 & $231 \mathrm{II}$ & 283 & 2677 & 168937 & & & 168737 & \multirow{4}{*}{$\begin{array}{l}\text { id } \\
\text { of income } \\
\text { account }\end{array}$} & \multirow{12}{*}{ (2) } \\
\hline Ka & Concumption of fisad nastall & & & & & & & & & & & \\
\hline B.In'B.1־n & $\begin{array}{l}\text { Yalue added, netiNet domestic } \\
\text { product }\end{array}$ & 64235 & 10305 & 19874 & 20808 & 2125 & 140386 & & & 140386 & & \\
\hline B.11 & $\begin{array}{l}\text { External balance of goods and } \\
\text { services }\end{array}$ & & & & & & & 13531 & & 13531 & & \\
\hline 0.1 & Compensation of employees & & & & 82871 & & 82871 & 252 & & 83123 & \multirow{8}{*}{ 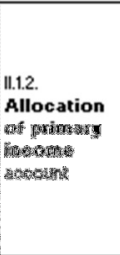 } & \\
\hline 0.2 & Taxes on production and imports & & & 24527 & & & 24527 & 454 & & 24982 & & \\
\hline D3 & Subsidies & & & -1421 & & & -1421 & -1388 & & -2808 & & \\
\hline B.2g & Gross operating surplus & 29229 & 6815 & 3201 & 6822 & 544 & 46612 & & & 46612 & & \\
\hline 83 & 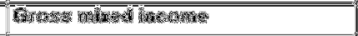 & & & & $1767 \%$ & & 17676 & & & 17676 & & \\
\hline Pax & 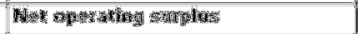 & 13 It: & 14:2 & $=5$ & 646 & -8 & 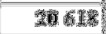 & & & 20618 & & \\
\hline 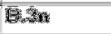 & 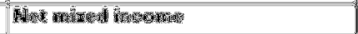 & & & & (14) & & 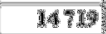 & & & 14 & & \\
\hline rets & 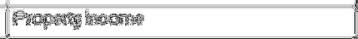 & 20218 & $25 \%$ & 13. & Indat & 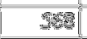 & 3552 & 25 ond & & Notis & & \\
\hline Rfig & 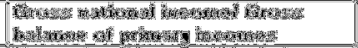 & WE & 2010 & 27 & 1110 & 慗艘 & 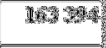 & & & 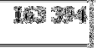 & \multirow{6}{*}{\multicolumn{2}{|c|}{$\begin{array}{l}\text { 11.2. Secondary } \\
\text { distribution income } \\
\text { account }\end{array}$}} \\
\hline Ten & 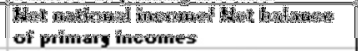 & 67 & 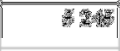 & 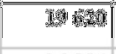 & Tot 3an & nes & 138 歌称 & & & Not 0 & & \\
\hline D.5 & Current taxes on income, wealth, etc & & & 16084 & & & 16084 & 28 & & 16112 & & \\
\hline D.61 & Social contributions & 1711 & 3773 & 19621 & 50 & 49 & 25204 & 60 & & 25264 & & \\
\hline D.62 & $\begin{array}{l}\text { Social benefits other than social transfers } \\
\text { in kind }\end{array}$ & & & & 29600 & & 29600 & 142 & & 29742 & & \\
\hline 0.7 & Other current transfers & 934 & 2257 & 2141 & 6667 & 2325 & 14324 & 2899 & & 17222 & & \\
\hline B.6g & Gross disposable income & 9473 & 5000 & 32232 & 115202 & 3199 & 165107 & & & 165107 & \multirow{3}{*}{\multicolumn{2}{|c|}{$\begin{array}{l}\text { 11.3. Redistribution } \\
\text { of income in kind } \\
\text { angsent }\end{array}$}} \\
\hline B.6n & Net disposable income & -5821 & 4327 & 28975 & 106627 & 2648 & 136756 & & & 136756 & & \\
\hline D. & 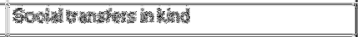 & & & & 22149 & & 2436 & & & 22139 & & \\
\hline$R_{3}$ & 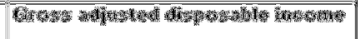 & 9.473 & 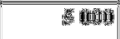 & 13 sout & 1373 & $-2 x$ & I6) 197 & & & 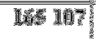 & \multirow{10}{*}{\multicolumn{2}{|c|}{ 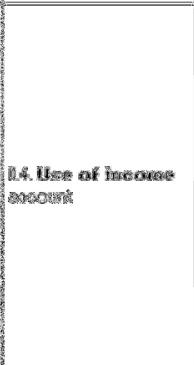 }} \\
\hline 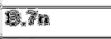 & 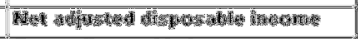 & 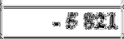 & 437 & 10 & 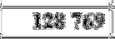 & -767 & 136756 & & & 1346756 & & \\
\hline 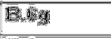 & 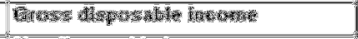 & $47 x^{3}$ & S6at & $23 \times 2$ & 19502 & 3 & 66: 197 & & & $16 \%$ & & \\
\hline Bhen & 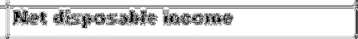 & $=$ 焉 & 437 & 1878 & 10064 & $264+5$ & 13678 & & & 13076 & & \\
\hline Fit & 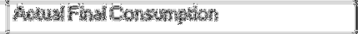 & & & & & & & & [48694 & 1464 & & \\
\hline Fus & Ther & & & & & & & & Ming & In & & \\
\hline$\overline{\mathrm{IV}}$ & 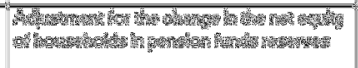 & & & & 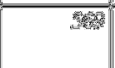 & & 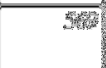 & & & 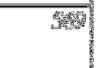 & & \\
\hline 28 & 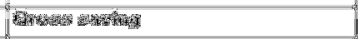 & & & & & & & & & & & \\
\hline 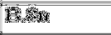 & 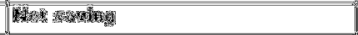 & & & & & & & & & & & \\
\hline 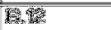 & 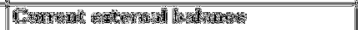 & & & & & & & & & & & \\
\hline
\end{tabular}

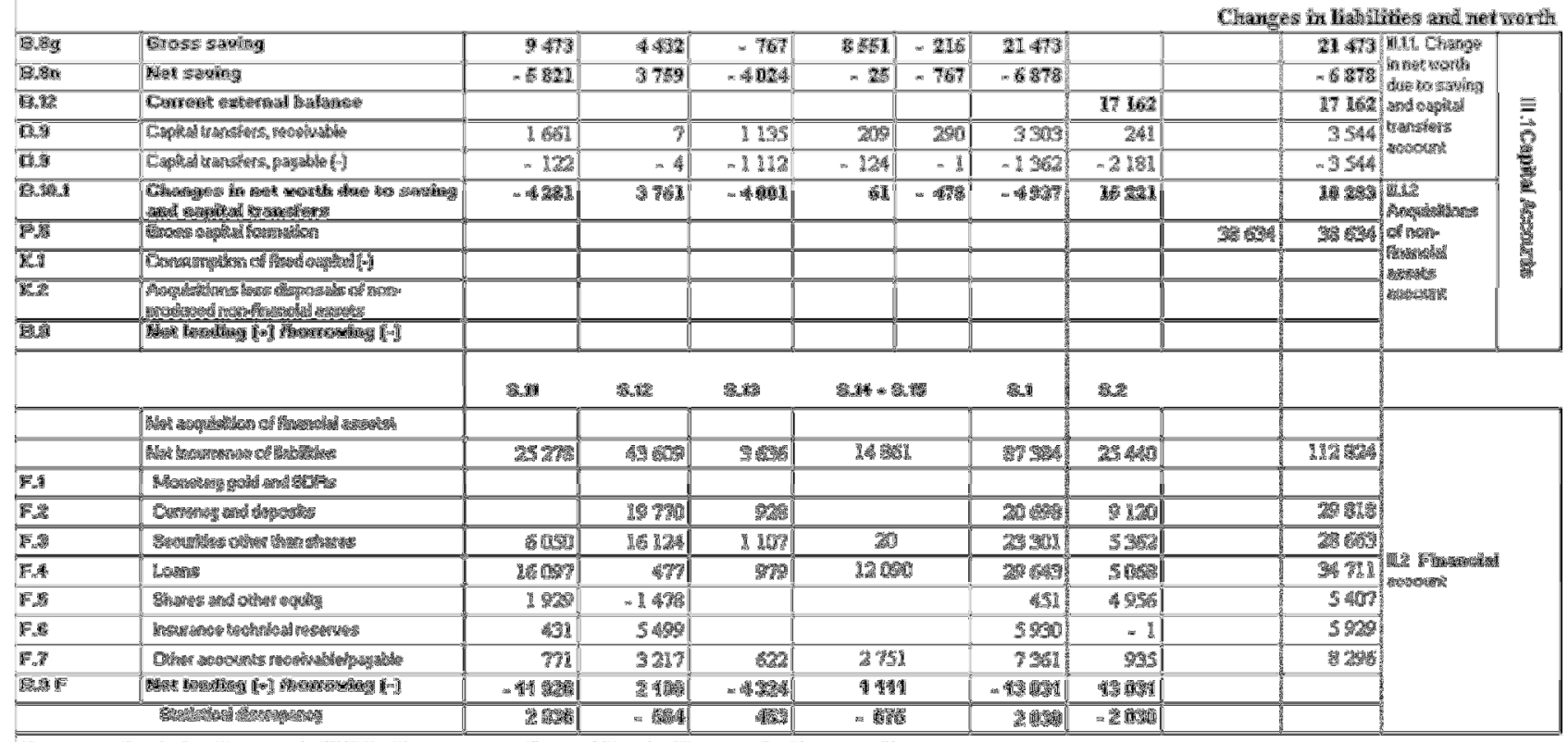

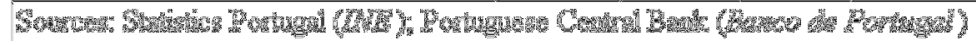




\section{Appendix B. Sources of information and methodological details of the SAM of Mozambique in 2007 (Tables: 5, 7 and 13).}

All the work undertaken for the application to Mozambique was centred around the data of the national accounts provided by the following two main sources of information:

\section{Instituto Nacional de Estatística de Moçambique}

(http://www.ine.gov.mz/indicadores_macro_economicos/cn/);

\section{World Bank Databank by Country - Mozambique}

(http://data.worldbank.org/country/mozambique).

The former was used as the main source, while the latter provided complementary information. Thus, the information from the World Bank Databank was used only when the Statistical Office did not have the required information available, although in many cases both sources contained information about the same transactions (usually different).

Only the information available online (see the links after the names of the sources) was worked on, since the various personal attempts that were made to enter into contact with the main source did not receive any reply. Therefore, from the main source of information, it was only possible to work with the items relating to GDP, calculated using the three known approaches (production, expenditure and income).

All the data that were worked upon were collected in September and October 2010.

SAMs for Mozambique in 1994 and 1995 were constructed by the Trade and Macroeconomics Division of the International Food Policy Research Institute (IFPRI) under the scope of the research project entitled "Macroeconomic Reforms and Regional Integration in Southern Africa", which comprised six countries including Mozambique (Arndt et al., 1998) ${ }^{10}$. Those SAMs were constructed as databases for the modelling approach used, namely computable general equilibrium (CGE) modelling. Their underlying conceptual framework was the same as the one that is used in this paper. However the National Accounts were not their main source of information and they were designed in accordance with the modelling purposes that they were intended to serve, even including an attempt to cover a part of production and consumption that was not measured by the National Accounts. When the work on the SAM for Mozambique in 2007 (which is the one presented in this paper) was started in June 2009, contact was made with one of the members of the team involved in that project in order to know if any updates had been made in the meantime, and

\footnotetext{
${ }^{10}$ This was a project "specially designed to examine a variety of macroeconomic and trade policy reform packages for their ability to enhance agricultural performance and contribute to economic growth and poverty reduction" (Tarp et al., 2002: ix).
} 
an aggregated version for 2001 was then provided. Due to its characteristics and the year to which it refers, it was only considered once, as described below (b.1).

The description below will deal with the SAM blocks, as described in Section 3.1. The sources of information will be referred to using the numbers that were associated with these items above and the SAM cells will be referred to using the description contained in Table 2.

a) Production - P (cell: $\left.\mathrm{t}_{a, \mathrm{p}}\right)$ was calculated by adding to the Gross Added Value at factors cost $\left(\mathrm{t}_{\mathrm{f}, a}\right)$ the Intermediate Consumption $\left(\mathrm{t}_{\mathrm{p}, a}\right)$ and the Net Taxes on Production $\left(\mathrm{t}_{\mathrm{dic}, a}\right)$.

b) Domestic Trade.

b.1) Intermediate Consumption - IC (cell: $\mathrm{t}_{\mathrm{p}, a}$ ) was calculated by applying the weight of the IC in the $\mathrm{GDP}_{\mathrm{pm}}$ (calculated through the production approach) of the SAM for 2001, provided by the above-mentioned team of the IFPRI, to the $\mathrm{GDP}_{\mathrm{pm}}$ for 2007 (calculated through the expenditure or income approach and given by source 1).

b.2) Final Consumption - FC (cell: $t_{p, d i c}$ ) was given directly by source 1 . No information was found on the final consumption of non-profit institutions serving households.

b.3) Gross Capital Formation - GCF (cell: $\mathrm{t}_{\mathrm{p}, \mathrm{dik}}$ ) was given directly by source 1.

c) External Trade

c.1) Imports - IM (cell: $\mathrm{t}_{\mathrm{rw}, \mathrm{p}}$ ) was given directly by source 1.

c.2) Exports - EX (cell: $t_{\mathrm{p}, \mathrm{rw}}$ ) was given directly by source 1 .

d) Trade and Transport Margins - TTM (cell: $t_{\mathrm{p}, \mathrm{p}}$ ) at this level of aggregation amounted to zero.

e) Net indirect taxes or net taxes on production and imports

e.1) Net Taxes on Production - NTA (cell: $\mathrm{t}_{\mathrm{dic}, a}$ ) were calculated from source 1 by subtracting the subsidies paid from taxes on production.

e.2) Net Taxes on Products - NTP (cell: $\left.t_{\text {dic,p }}\right)$ were given directly by source 1 .

f) Compensation of factors of production - CFP

f.1) Gross Added Value - CFP-GAV (cell: $\mathrm{t}_{\mathrm{f}, a}$ ). The total was calculated from source 1 by subtracting the net taxes on production from the gross added value at basic prices. The breakdown by labour and own assets was calculated from the difference between the corresponding column totals and the part received from the rest of the world $\left(t_{f, r w}\right)$. 
f.2) Gross National Income - CFP-GNI (cell: $t_{d i c, f}$ ). The total was calculated from source 1 by subtracting the net indirect taxes from the gross national product (at market prices). The compensation of labour was given directly by source 1, with the total compensation of own assets being calculated from the difference between the total (GNI) and the compensation of labour.

f.3) Compensation of factors from and to the Rest of the World - CFP (cells: $\left.t_{f, r w} ; t_{r w, f}\right)$. The difference (or balance) between the total compensation of factors from and to the rest of the world, which corresponds to the income balance in Table 13, is the difference between the gross domestic product and the gross national product, given by source 1. Each cell was calculated by applying to that balance the structure of receipts and payments of the net income, or income balance (of the balance of payments), given by source 2 . In the conversion from United States dollars (US\$) to meticais the rate that was adopted was the one used by that same source in the imports and exports of goods and services (1 US $\$ \cong$ 25.858 meticais).

g) Current Transfers - CT

g.1) CT within domestic institutions (cell: $t_{\text {dic,dic }}$ ), was unavailable.

g.2) CT from and to the Rest of the World (cells: $t_{\text {dic,rw }} ; t_{\text {rw,dic }}$ ), To measure the difference (or balance) between the total CT from and to the rest of the world, which corresponds to the current transfers balance in Table 13, the net current transfers or current transfers balance (of the balance of payments), given by source 2, was adopted, since this was the only available information. In the conversion of currencies, exactly the same procedure as the one described in f.3 was adopted.

h) Capital Transfers - KT

h.1) KT within domestic institutions (cell: $t_{\text {dik,dik }}$ ) was unavailable.

h.2) KT from and to the Rest of the World (cells: $t_{\text {dik,rw; }} t_{r w, d i k}$ ). To measure the difference (or balance) between the total KT from and to the rest of the world, which corresponds to the capital account balance in Table 13, the net capital account (of the balance of payments), given by source 2, was adopted, since this was the only available information. In the conversion of currencies, exactly the same procedure as the one described in f.3 was adopted. 
i) Financial Transactions - FT

i.1) FT within domestic institutions (cell: $t_{\text {dif,dif }}$ ) was unavailable.

i.2) FT from and to the Rest of the World (cells: $t_{\text {dif,rw }} ; t_{r w, d i f}$ ) The difference (or balance) between the total FT from and to the rest of the world, which corresponds to the financial account balance in Table 13, is the amount referred to in h.2) with an opposite mathematical sign.

j) Gross Saving - S (cell: $\left.t_{d i k, d i c}\right)$ is the part of the disposable income, calculated in Section 3.3 that was not spent in final consumption (FC).

k) Net borrowing/lending - NLB (cell: $t_{\text {dik,dif }}$ ), NL in our application - is the balance of the financial account in Table 14, referred to in i.2). 